ERIA - DP - 2013-14

ERIA Discussion Paper Series

\title{
Impact of Disasters and Disaster Risk Management in Singapore: A Case Study of Singapore's Experience in Fighting the SARS Epidemic
}

\author{
Allen Yu-Hung LAI ${ }^{1}$ \\ The Institute of Health Economics and Management, ESSEC \\ Business School - Asia Pacific \\ SECK L. TAN ${ }^{2}$ \\ National University of Singapore
}

August 2013

\begin{abstract}
Singapore is vulnerable to both natural and man-made disasters alongside its remarkable economic growth. One of the most significant disasters is the Severe Acute Respiratory Syndrome (SARS) epidemic in 2003. The SARS outbreak was eventually contained through a series of risk mitigating measures introduced by the Singapore government. This would not be possible without the engagement and responsiveness of the general public. This paper begins with a description of Singapore's historical disaster profiles, the policy and legal framework in the all-hazard management approach. We use a case study to highlight the disaster impacts and insights drawn from Singapore's risk management experience with specific references to the SARS epidemic. We draw on the lesson-learning from Singapore's experience in fighting the SARS epidemic, and discuss implications for future practice and research in disaster risk management. The implications are explained in four aspects: staying vigilant at the community level, remaining flexible in a national command structure, the demand for surge capacity, and collaborative governance at regional level. This paper concludes with a presence of the flexible command structure on both the way and the extent it was utilized. This helps to explain the success level of the containment of the SARS epidemic.
\end{abstract}

Keywords: Disaster risk, SARS, epidemics, infectious disease, Singapore

JEL classification: Q54, Q52, O53 


\section{Introduction}

Situated in Southeast Asia yet outside the Pacific Rim of Fire, Singapore is fortunate enough to have been spared from major natural disasters such as typhoons, floods, volcanic eruptions, and earthquakes. However, this does not imply that Singapore is safe, or immune from being affected by disasters. Singapore houses a population of 5.2 million, a ranking of the third highest population density in the world. About 80 \% of Singapore's population resides in high-rise buildings (Asian Disaster Reduction Center, 2005). A major disaster of any sort could inflict mass casualties and extensive destruction to properties in Singapore. Clearly, like its neighboring countries, Singapore is also vulnerable to both natural and man-made disasters alongside its remarkable economic growth. The potential risks may result from its dense population, intricate transportation network, or a transnational communicable disease. Moreover, Singapore can be affected by the situations in surrounding countries. For example, flooding in Thailand and Vietnam may affect the price of rice sold in Singapore.

Indeed, Singapore in her short history of 47 years has experienced a small number of disasters. Chief among these, the Severe Acute Respiratory Syndrome (SARS) epidemic in 2003 was the most devastating. The SARS outbreak brought about far-reaching public health and economic consequences for the country as a whole. Fortunately, the outbreak was eventually contained through a series of risk mitigating measures introduced by the Singapore government and the responsiveness of all Singaporeans. It is important to point out that these risk mitigating measures, along with the public's compliance, were swiftly adjusted to address the volatile conditions - such as when more epidemiological cases were uncovered.

In this paper, we introduce Singapore's all-hazard management framework as well as the insights drawn from Singapore's risk management experience with specific references to the SARS epidemic. To achieve our research objective, we utilized a triangulation strategy of various research methodologies. For understanding the principles and practices of Singapore's approach to disaster risk management, the research methods employed here are an historical analysis of official documents obtained from the relevant Singapore government agencies as 
well as international organizations, literature reviews, quantitative analysis of economic impacts, qualitative interviews with key informants (e.g. public health professionals and decision-makers), and email communications with frontline managers from the public sector (e.g. the Singapore Civil Defense Force, the Communicable Disease Centre) and non-governmental organizations. The authors also employed the 'cultural insider' approach by participating in epidemic control against SARS. ${ }^{3}$ In particular, we use the method of case study to illuminate Singapore's approach to disaster risk management. The rationale of doing a case study of SARS along with Singapore's all-hazard approach is that the case study can best showcase the contextual differences, those being political, economic, and social. This case study aims to highlight the lessons drawn from past experiences in a specific context and timeframe, through which we are able to focus more on the nature of the risks, and the processes and the impacts of the disaster risk management and policy intervention. We also examined relevant literature on risk mitigating measures against communicable diseases in order to establish our conclusions. We evaluated oral accounts provided by key health policy decision-makers and experts for valuable insights. It is our hope that through these rigorous methodological approaches we ensure our conclusions are valid and reliable.

The research contribution of this paper is significant because it offers empirical evidence on the role of the whole-of-government approach to risk mitigation of the SARS epidemic. Applying the approach to a case study, our research enriches the vocabulary of risk management, adding to the body of knowledge on disaster management specific to the region of Southeast Asia. Indeed, the dominant perspective in this field holds that the state must be able to exercise brute force and impose its will on the population (Lai and Tan, 2012). However, as shown in our paper, this dominant perspective is incomplete as the exercise of authority and power from the government is not necessarily sufficient to contain the transmission of transnational communicable diseases. Success in fighting epidemics, as most would agree, is also contingent on a concerted effort of partnership between governmental authorities and the population at large. 
This paper has four main sections. Following this introduction, we provide an overview of Singapore's historical disaster profiles. Second, we introduce the policy and legal framework, and budgetary allocations for risk mitigation in Singapore. Third, we detail a case study of Singapore's experience in fighting SARS, as well as the impact of SARS on Singapore in its economic, healthcare, and psychosocial aspects. In the fourth section, we discuss the implications for practice and future research in disaster risk management, followed by conclusions.

\section{Singapore's Historical Disaster Profile}

Singapore has experienced a small number of disasters since it was founded in 1965 (Table 1). In this section, we briefly provide an historical account of Singapore's disaster risk profiles including earthquakes, floods, epidemics, civil emergencies, and haze. According to the Centre for Research on the Epidemiology of Disasters (CRED) EM-DAT, ${ }^{4}$ an emergency event is classified as a disaster if it meets at least one of the following criteria: 10 or more people reported killed, 100 people reported affected, the declaration of a state emergency, and the call for international assistance. However, to provide an overview of Singapore's disaster profiles, this paper lists all major public emergencies in the city-state from 1965 onwards.

Table 1: A Chronological Profile of Singapore's Major Disaster Events from 1965-2011

\begin{tabular}{llcc}
\hline Year/Event & $\begin{array}{l}\text { Nature of } \\
\text { Disaster }\end{array}$ & $\begin{array}{c}\text { Number of } \\
\text { People } \\
\text { Affected }\end{array}$ & $\begin{array}{c}\text { Number of } \\
\text { People Killed }\end{array}$ \\
\hline \hline 1978/Greek tanker Spyros explosion & Industrial & 182 & 76 \\
1978/Floods & Natural & $>100$ & 7 \\
1986/ Hotel New World Collapse & Technological & 50 & 33 \\
1997/Southeast Asian Haze & Natural & $>100$ & Nil \\
2000/Hand Foot Mouth Disease & Natural & 3790 & 3 \\
2003/SARS & Natural & 238 & 33 \\
2006-07/Southeast Asian floods & Natural & $>100$ & Nil \\
2009/H1N1 avian influenza & Natural & 1,348 & 18 \\
\hline
\end{tabular}

Source: Various Government Reports 


\subsection{Risk of Earthquake and Tsunami}

Singapore has a low risk of earthquakes and tsunamis. Geographically, Singapore is located in a low seismic-hazard region. However, the high-rise buildings that are built on soft-soil in Singapore are still vulnerable to earthquakes from far afield (ADRC, 2005). This is because Singapore is at a distance (nearest) of $600 \mathrm{~km}$ from the Sumatran subduction zone and $400 \mathrm{~km}$ away from the Sumatra fault both of which have the potential of generating large magnitude earthquakes. This geographic vicinity may produce a resonance like situation within high-rise buildings on soft-soil. Recent tremors from the September 2009 Sumatra offshore earthquake were experienced in 234 buildings located mainly in the central, northern and western parts of Singapore. On the front of potential tsunamis, Singapore has developed a national tsunami response plan which is a multiagency government effort comprising of an early warning system, tsunami mitigation and emergency response plans, and public education.

\subsection{Risk of Flooding}

Though Singapore does not suffer from flood disasters due to the continuous drainage improvement works by the local authorities, the country has a risk of local flooding in some low-lying parts. The floods take place due to heavy rainfall that aggregates over short periods of time. The worst floods in Singapore's history took place on 2 December 1978. The floods claimed seven lives, forced more than 1,000 people to be evacuated, and the total damages reached SGD10 million (Tan, 1978). The swift and sudden floods in 1978 were caused by a combination of factors including torrential monsoon rains, drainage problems, and high incoming tides. Over the following years, Singapore saw a series of flash floods hit various parts of the city-state. For example, 2006-07 Southeast Asian floods hit Singapore on 18 December 2006 as a result of 366 mm rainfall in 24 hours. From 2010 onwards, Singapore has experienced a series of flash floods due to the higher-than-average rainfall. One severe episode occurred on16 June 2010 that flooded shopping malls and basement car parks in its most famous shopping area - Orchard Road. 


\subsection{Risk of Epidemics/Pandemics}

As per the reported historical disaster data from the CRED International Disaster Database, Singapore has suffered only two disaster events caused by epidemics. In 2000, Singapore experienced its largest known outbreak of Hand-Foot-Mouth Disease (HFMD) which affected more than 3,000 young children, causing 3 deaths. Later in 2003, SARS hit Singapore and it was Singapore's most devastating disaster to date. The SARS virus infected around 8,500 people worldwide and caused around 800 deaths. In Singapore, SARS infected 238 people, 33 of whom died of this contagious communicable disease. In 2009, novel avian influenza H1N1 struck Singapore, which affected 1,348 people with 18 deaths.

\subsection{Risk of Civil Emergencies}

Civil emergencies are defined as sudden incidents involving the loss of lives or damage to property on a large scale. They include 1) civil incidents such as bomb explosions, aircraft hijacks, terrorist hostage-taking, chemical, biological, radiological and explosive (CBRE) agents and the release of radioactive materials by warships, and 2) civil emergencies, for example major fires, structural collapses, air crashes outside the airport boundary, and hazardous material incidents. In Singapore, the Singapore Civil Defence Force (SCDF) is responsible for civil emergencies. Since 1965, Singapore has experienced several episodes of civil emergencies. For example, the Greek tanker Spyros explosion at the Jurong Shipyard in 1978 was Singapore's worst industrial disaster in terms of lives lost (Ministry of Labour, Singapore, 1979). In 1986, the six-storey Hotel New World collapse was Singapore's deadliest civil disaster claiming 33 lives. The collapse was due to structural faults. The SCDF, together with other rescue forces, spent 7 days on the whole relief operation. After the collapse, the government introduced more stringent regulations on construction building codes, and the SCDF went through a series of upgrades in training and equipment (Goh, 2004). 


\subsection{Risk of Haze}

Singapore experienced its first haze in the period of the end of August to the first week of November 1997 as a result of prevailing winds. The haze in 1997, called the Southeast Asian haze, was caused by slash and burn techniques adopted by farmers in Indonesia. The smoke haze carried particulate matter that caused an increase of acute health effects including increased hospital visits due to respiratory distress such as asthma, pulmonary infection, as well as eye and skin irritation. The haze also severely affected visibility in addition to increasing health problems. As a result, Singapore's health surveillance showed a 30\% increase in outpatient attendance for haze-related conditions (Emmanuel, 2000). Apart from healthcare costs, other costs associated with the haze included short-term tourism and production losses. A study by environmental economists of the 1997 Southeast Asian haze indicated a total of USD\$74.1 million in economic losses in Singapore alone. Singapore is actively involved in various regional meetings to deal with trans-boundary smoke haze pollution in order to reduce the risk (Singapore Institute of International Affairs, 2006).

\section{Disaster Risk Management in Singapore}

\subsection{Policy Framework for Disaster Risk Mitigation}

The Singapore government adopts a cross-ministerial policy framework - a Whole-of-Government Integrated Risk Management (WOG-IRM), for disaster risk mitigation and disaster management (APEC, 2011). This is a framework that aims to improve the risk awareness of all government agencies and the public, and helps to identify the full range of risks systematically. In addition, the framework identifies cross-agency risks that may have fallen through gaps in the system. This framework also includes medical response systems during emergencies, mass casualty management, risk reduction legislation for fire safety and hazardous materials, police operations, information and media management during crises and public-private partnerships in emergency preparedness. 
The WOG-IRM policy frame work in Singapore functions in peacetime and in times of crisis. It refers to an approach that all relevant agencies work together in an established framework, with seamless communication and coordination to manage the risk (Pereira, 2008). In peacetime, the home team comprises of four core agencies at central government level. These four agencies are the Strategic Planning Office, the Home front Crisis Ministerial Committee (HCMC), the National Security Coordination Secretariat, and the Ministry of Finance at the policy layer (see Figure 1). Among them, the Strategic Planning Office provides oversight and guidance as the main platform to steer and review the overall progress of the WOG-IRM framework. During peacetime, the Strategic Planning Office convenes meetings quarterly for the permanent secretaries from the various ministries across government. In a crisis, the Home front Crisis Management system provides a 'ministerial committee' responsible for all crisis situations in Singapore.

In the WOG-IRM structure, the HCMC is led by the Ministry of Home Affairs (MHA). In peacetime, MHA is the principal policy-making governmental body for safety and security in Singapore. In the event of a national disaster, the MHA leads at the strategic level of incident management. The incident management system in Singapore is known as the Home front Crisis Management System (HCMS). Under the HCMS, the SCDF is appointed as the Incident Manager, taking charge of managing the consequences of disasters and civil emergencies. Reporting to the HCMC is an executive group known as the Home front Crisis Executive Group (HCEG), which is chaired by the Permanent Secretary for MHA. The HCEG is in charge of planning and managing all types of disasters in Singapore. Within the operation allayer, there are various functional inter-agency crisis management groups with specific responsibilities, integrated by the various governmental crisismanagement units. At the tactical layer, there are the crisis and incident managers who supervise service delivery and coordination. The Singapore government holds relevant ministries accountable in accordance to the nature and scope of the disaster. Among those ministries and government agencies, the SCDF is the major player in risk mitigation and management for civil emergencies. Now, let us look into the SCDF in more detail. 
For civil security and civil incidents, the Singapore Civil Defence Force (SCDF) ${ }^{5}$ is Singapore's leading operational authority - the Incident Manager for the management of civil emergencies. The SCDF is responsible for leading and coordinating the multi-agency response under the Home front Crisis Management Committee. The SCDF operates a 3-tier command structure, with Headquarters (HQ) SCDF at the apex commanding 4 Land Divisions. These Divisions are supported by a network of Fire Stations and Fire Posts strategically located around the island. The SCDF also serves the following pivotal functions. The SCDF provides effective 24hour fire fighting, rescue and emergency ambulance services. The SCDF developed the Operations Civil Emergency (Ops CE) Plan - a national contingency plan. When Ops CE is activated, the SCDF is vested with the authority to direct all response forces under a unified command structure, thus enabling all required resources to be pooled. However, the WOG-IRM policy framework only came to existence when Singapore encountered SARS.

The SARS epidemic in 2003 was an institutional watershed for Singapore's approach to risk mitigation and disaster management (Pereira, 2008). Prior to the SARS epidemic, Singapore's Executive Group ${ }^{6}$ mainly focused on crises or disasters that were civil defense in nature. These emergencies were merely conceived to be well managed by a solitary incident manager, supported by other relevant agencies. A specific multi-sectoral governance structure was not considered necessary to handle the crisis. The SARS epidemic challenged the prevailing Home front Crisis Management structure as the epidemic transcended just managing civil defense incidents. The policymakers realized the necessity to adopt a comprehensive disaster management framework, an all-hazard approach that includes a mechanism for seamless integration at both the strategic and operational levels among various government agencies. To this end, Singapore revamped its Home front Crisis Management framework to produce the current inter-agency structure. 
Figure 1: Whole-of-Government Integrated Risk Management Policy Framework

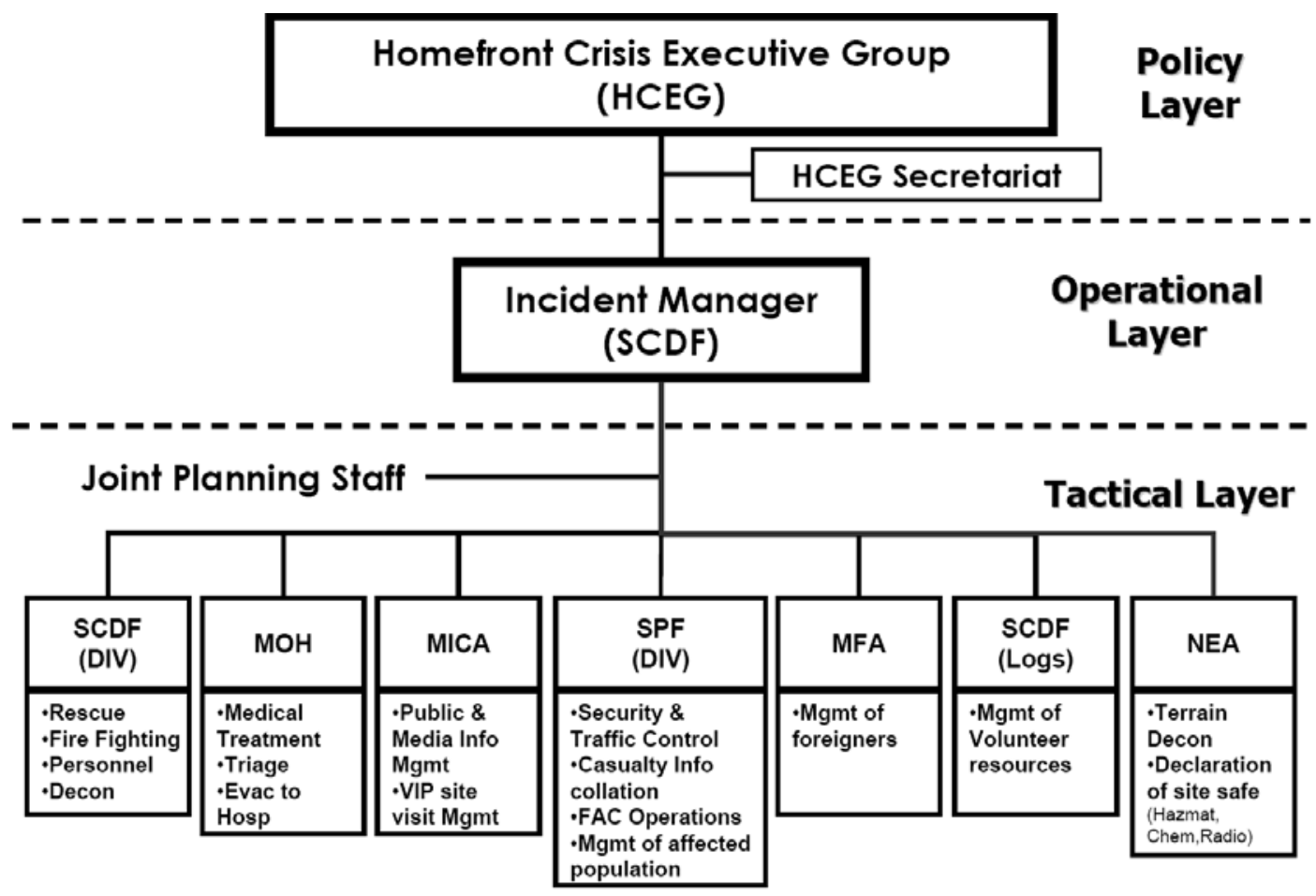

Source: Asian Conference on Disaster Reduction (2010)

\subsection{Legal Framework in Disaster Reduction}

The main legislation supporting emergency preparedness and disaster management activities in Singapore are the Civil Defence Act of 1986, the Fire Safety Act of 1993, and the Civil Defence Shelter Act of 1997. The Civil Defence Act provides the legal framework for, amongst other things, the declaration of a state of emergency and the mobilization and deployment of operationally-ready national service rescuers. The Fire Safety Act (1993) provides the legal framework to impose fire safety requirements on commercial and industrial premises, as well as the involvement of the management and owners of such premises in emergency preparedness against fires; and The Civil Defence Shelter Act provides the legal framework for buildings to be provided with civil defense shelters for use by persons to take refuge during a state of emergency. To tackle disease outbreak, Singapore had earlier promulgated the Infectious Disease Act in 1977. This legislation is jointly administered by the MOH and the National Environment Agency (NEA). 


\subsection{Budgetary Allocations}

Unlike most governments that make regular national budgetary provision for potential disaster relief and early recovery purposes, the Government of Singapore makes no annual budgetary allocations for disaster response because the risks of a disaster are low (Global Facility for Disaster Reduction and Recovery, 2011, p.24). However, the Singapore government can swiftly activate the budgetary mechanisms or funding lines in the event of a disaster and ensure these lines are sufficiently resourced with adequate financial capacity.

\section{Case Study: Singapore's Experience in Fighting SARS Epidemic}

To illuminate Singapore's approach to disaster management, we now use a case study of Singapore's fight against SARS to highlight policy learning and lessondrawing in a specific context and timeframe. This case study has three sections. We first introduce the epidemiology of SARS in Singapore. In the second section, we describe the impact caused by SARS epidemics on Singapore in the economic, healthcare, and psychosocial aspects. In the third section, we demonstrate Singapore's risk mitigating management, and detail the government's risk mitigating measures to contain the epidemic.

\subsection{Epidemiology of SARS in Singapore}

SARS hit Singapore in early 2003. But what began as a few isolated cases swiftly turned into a major public health emergency within a few short weeks. In early March 2003 the first Singaporean to contract SARS was hospitalized upon her return from Hong Kong. As it turned out, she had contracted SARS from a supercarrier while both were staying on the same floor of the M Hotel. That supercarrier - a physician from China - was later identified by the World Health Organization (WHO) to be the primary source of infection for multiple cases of SARS worldwide (Centers for Disease Control and Prevention, 2003). Back in Singapore, this first SARS victim quickly infected 21 others. In late July 2003, 
among all SARS affected countries, Singapore reported 238 probable cases (see Table 2). By the time, Singapore was removed from the WHO advisory list on 31 May 2003, 205 (86\%) had recovered while 33 (14\%) had died. A further breakdown reveals that 8 cases (3\%) were infected while abroad whereas 97 cases (41\%) were healthcare workers (WHO, 2003a).

Table 2: SARS Numbers Worldwide (as of the 31 December 2003)

\begin{tabular}{lll}
\hline Country & Number of Cases & Number of death (fatality rate) \\
\hline \hline Singapore & 238 & $33(13.8 \%)$ \\
Taiwan & 346 & $37(10.6 \%)$ \\
Hong Kong & 1,755 & $299(17 \%)$ \\
Vietnam & 63 & $5(7.9 \%)$ \\
China & 5,327 & $349(6.5 \%)$ \\
Canada & 251 & $43(17 \%)$ \\
\hline
\end{tabular}

Source: WHO (2003b)

\subsection{SARS's Impact on Singapore}

Economic Impact

Singapore is a small open economy. External shocks can result in high levels of volatility resonating across the domestic economy. These shocks in turn would bring about higher levels of risk and uncertainty in Singapore. At the beginning of 2003, Singapore's economic outlook was clouded by the Iraq War and its impact on oil prices (Attorney-General's Chambers, 2003). The unexpected outbreak of SARS led to greater uncertainty in the Singapore economy. Singapore's financial markets were severely affected due to the loss of public confidence and reduced floor trading. The impact of SARS on the stock market reflected in the Straits Times Index (STI) (see Figure 2). The market did not react well to the SARS epidemic. In the first fortnight of the epidemic, the STI closed down 76 points. Even though more cases were reported, the STI climbed progressively up 86 points over the next fortnight, eclipsing the earlier falls. This could be attributed to the strict measures which the Singapore government introduced. The STI remained relatively stable over the 
immediate fortnight as new cases were reported. However, it started a downward plunge over the following fortnight as the number of cases peaked once more. The STI plunged 96 points. However, the resilience of the STI was shown when it climbed back up, surpassing the level reported at the beginning of the SARS period. The volatility of the STI demonstrates the vulnerability of a small open economy from exogenous forces - in this case, the SARS epidemic.

Figure 2: SARS Probable Cases and Straits Times Index (Closing) $\left(25^{\text {th }}\right.$ February to $6^{\text {th }}$ May 2003)

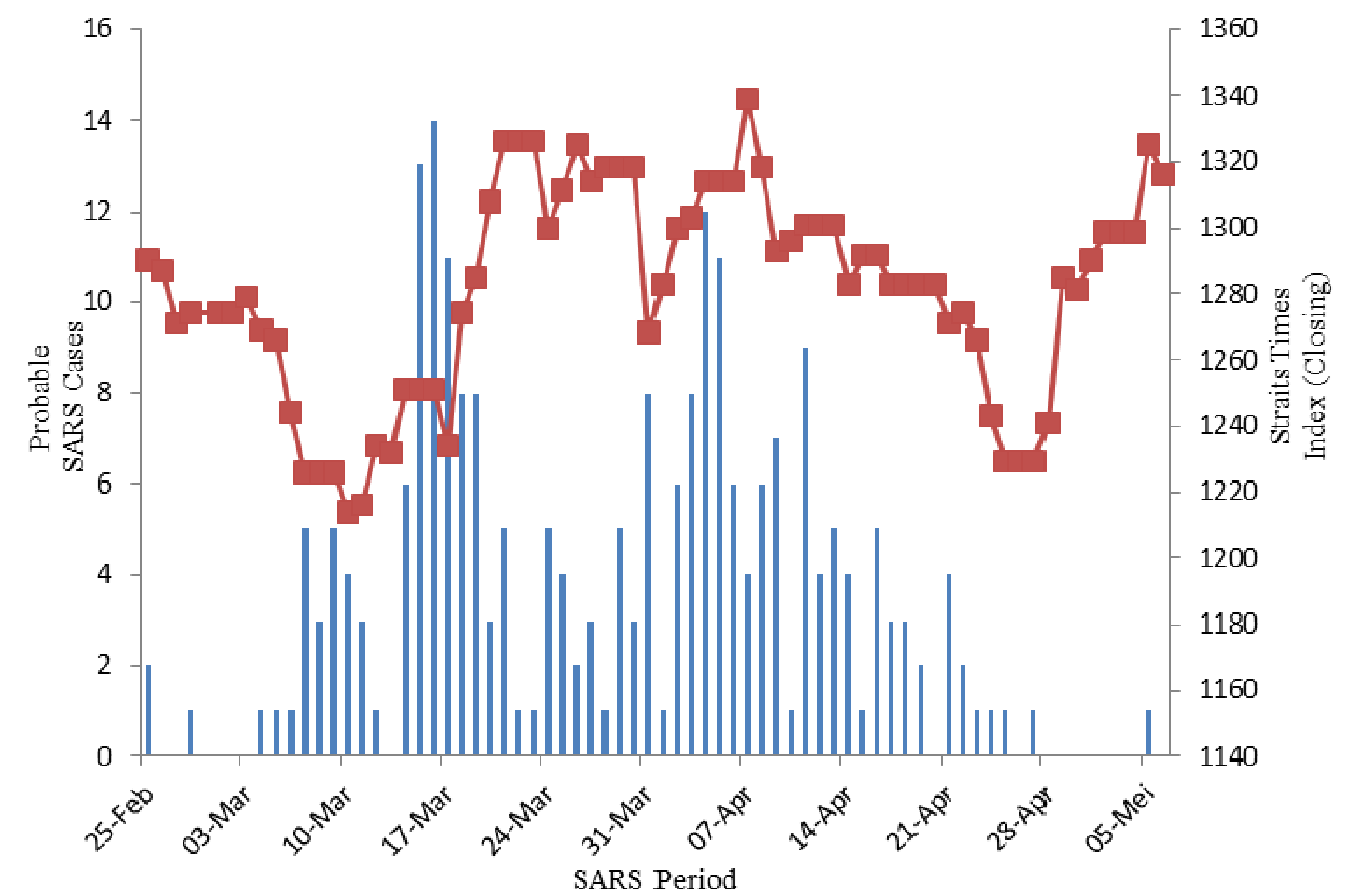

Source: Straits Times Index available at http://quotes.stocknod.com(accessed April 15, 2012); Ministry of Health (2003a) 
Figure 3: Impact of SARS on Singapore's Domestic Economy*

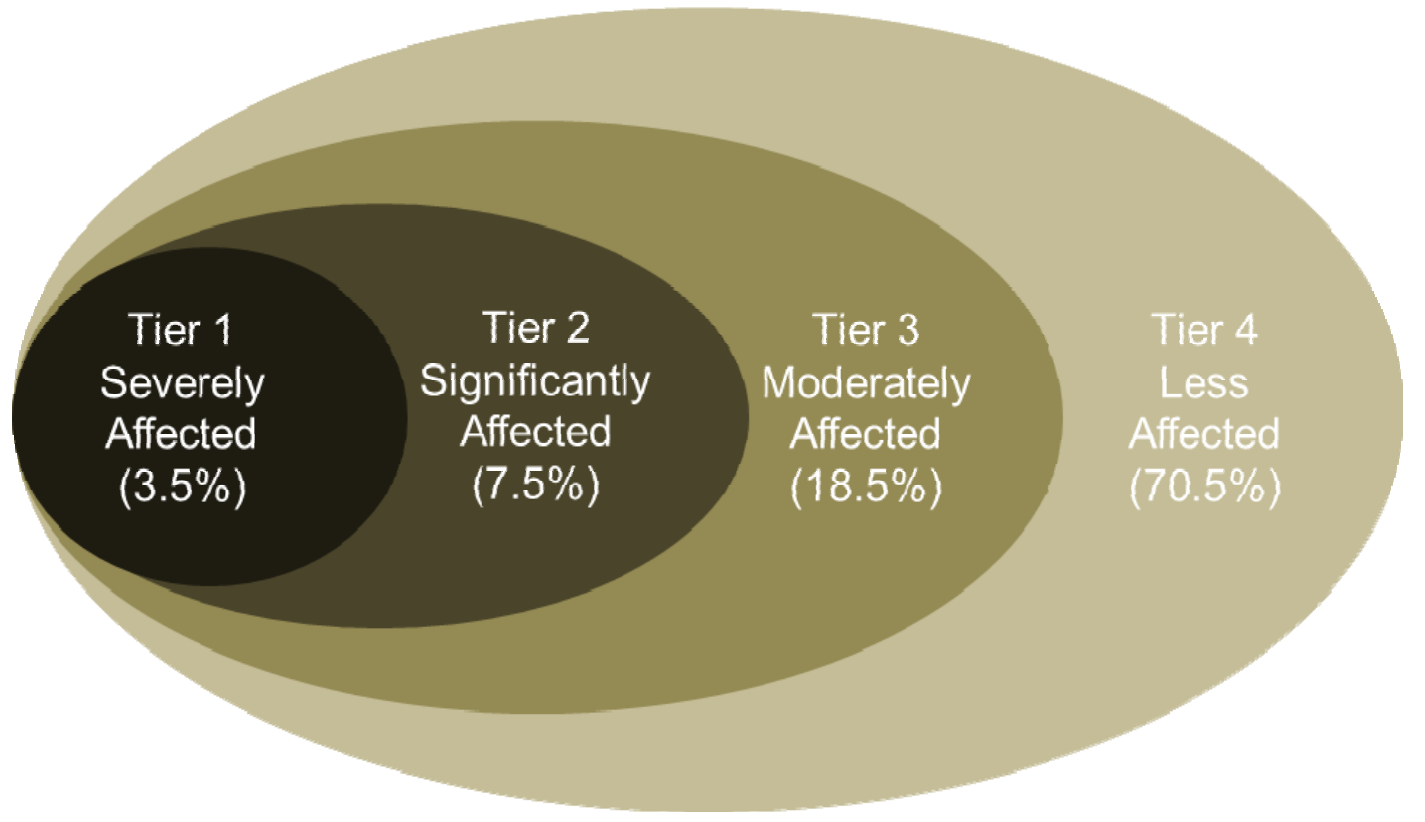

Note: *MAS internal estimates

Source: Monetary Authority Singapore, Annual Report 2003/2004

Table 3: Impact of SARS on Singapore's Domestic Economy

\begin{tabular}{llc}
\hline Tier & Industry & Percentage in GDP \\
\hline \hline $\mathbf{1}$ (Severely) & Hotels, Air-Transport & $3.50 \%$ \\
$\mathbf{2}$ (Significantly) & Restaurants, Retail Trade, Land Transport & $7.50 \%$ \\
$\mathbf{3}$ (Moderately) & Real Estate, Financial Services & $18.50 \%$ \\
$\mathbf{4}$ (Less) & Manufacturing, Construction, Post and & $70.50 \%$ \\
& Communications, Wholesale Trade, Sea & \\
& Transport, Service Allied to Transport & \\
\hline
\end{tabular}

Source: Monetary Authority Singapore, Annual Report 2003/2004

SARS was the one single activity which contributed to the volatility of Singapore's Gross Domestic Product (GDP) in 2003. The Ministry of Trade and Industry (MTI) revised the forecast for Singapore's annual GDP growth down from $3 \%$ to $0.5 \%$. This forecast was later revised upwards to $2.5 \%$. There were a number of channels by which the SARS epidemic affected the economy. The economic impacts will be discussed from the positions of demand and supply shocks. The main economic impact of the SARS outbreak was on the demand side, as consumption and the demand for services declined (Henderson, 2003). The 
economic consequence caused fear and anxiety among Singaporeans and potential tourists to Singapore. The hardest and most directly hit were the tourism, retail, hospitality and transport-related industries, for example airline, cruise, hotel, restaurant, travel agent, retail and taxi services, and their auxiliary industries (see Figure 3 and Table 3). Visitor arrivals fell by one third in March 2003, and two thirds in April 2003. This had a direct impact on hotel occupancy rates, which declined sharply to 30\% in late April 2003. Cancellation or postponement of tourism events increased by about $30-40 \%$. Revenues of restaurants dropped by $50 \%$ while revenues of the travel agents decreased by $70 \%$. SARS had an uneven impact on various sectors of the economy. A four-tiered framework to assess the impact on the respective sectors showed that Tier 1 industries, such as the tourism and travelrelated industries were most severely hit. Tier 1 industries account for 3.5\% of GDP. The Tier 2 industries, such as restaurants, retail and land transport industries were significantly hit, which account for $7.5 \%$ of GDP. The next two tiers were less directly affected by the SARS outbreak. Tier 3 industries include real estate and stock broking, which account for close to $19 \%$ of GDP. The remaining $70 \%$ of the domestic economy in Tier 4 includes manufacturing, construction and communications. These industries were not directly impacted by the outbreak of SARS. All in all, the estimated decline in GDP directly from SARS was $1 \%$, equaling SGD875 million.

Singapore experienced a significant drop in tourist arrivals where visitors usually stay for up to three days and transit onto their next destination. The trend for visitor inflow is that visitor inflows fall sharply. This is especially true in the case of Singapore, when visitor stays tend to be shorter and the high-end visitors stayed away. As a result, tourism and other related industries were nearly crippled due to a significant reduction in both leisure and business travel. For example, tourist arrivals saw a significant drop of $15 \%$ in March 2003. The drop in tourist arrivals was $67 \%$ in April 2003, and 65\% for the month of May 2003 until the first week of June 2003. The outcome was low visitor numbers relative to other months in 2003. See Figure 4 below. 
Figure 4: Singapore Visitors Numbers for the Year 2003

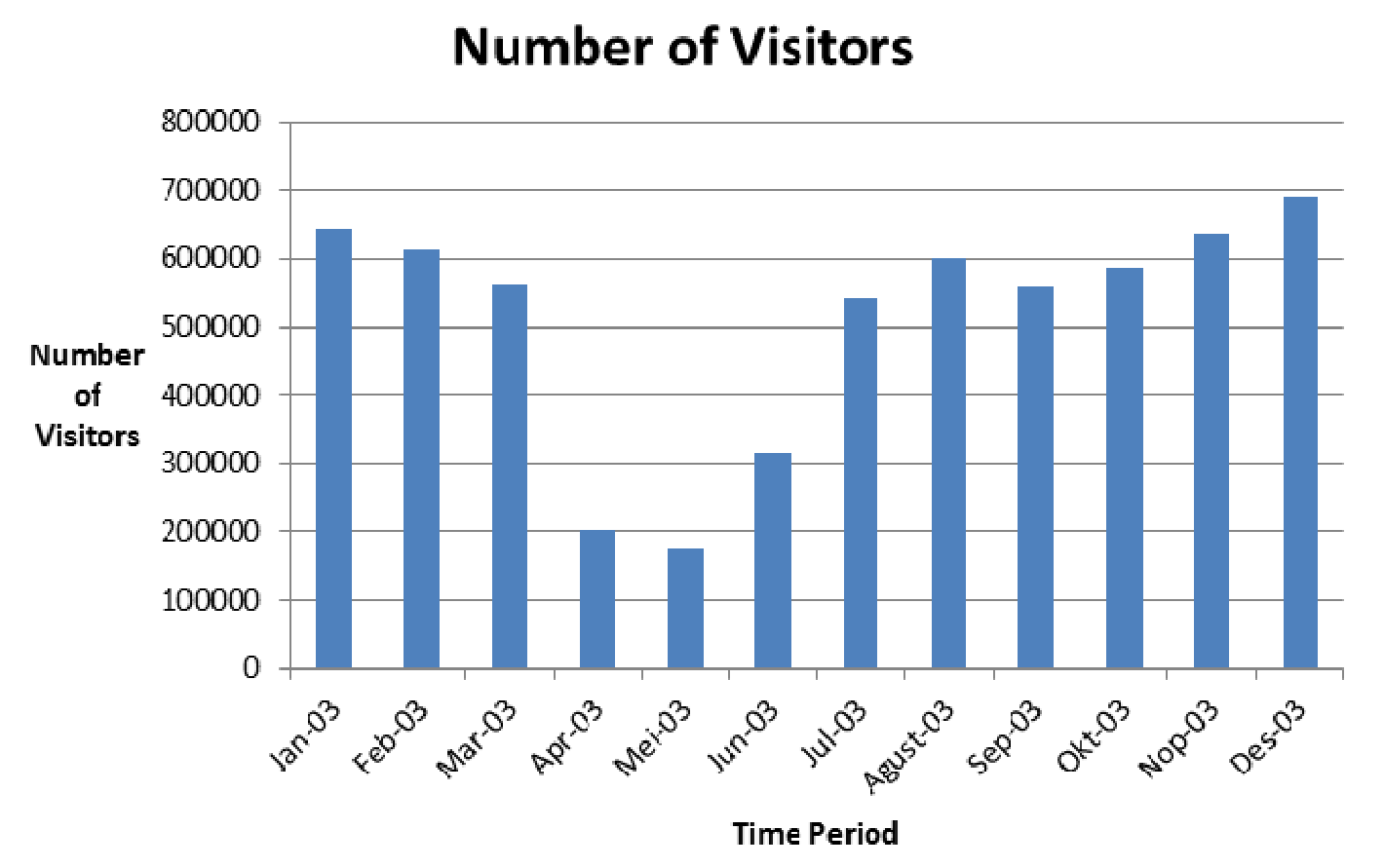

Source: Singapore Tourism Board (2003), “Annual Report on Tourism Statistics”

Visitors from around the world cancelled or postponed their trips to Singapore, causing a drastic decrease of total expenditure from visitors. (See Table 4) Plummeting visitor arrivals directly impacted hotel occupancy rates, which declined sharply to $30 \%$ in late April (See Table 5). The hotel occupancy rate plummeted from $72 \%$ to $42 \%$, compared to the normal level of $70 \%$ or above. The annual averages for hotel occupancy rates were $74.4 \%$ in 2002 , $67.3 \%$ in 2003 , and $80.6 \%$ in 2004. Singapore's national carrier, Singapore Airlines (SIA), faced a recordbreaking low passenger capacity of 29\% in April and May 2003.SIA cancelled approximately 30\% of its weekly schedules (Henderson, 2003). SIA laid off 414 employees, of which 129 were ground staff, as a consequence of a USD200 million loss in June 2003. 
Table 4: Change of Expenditure of Visitors and Incoming Flights from 2002 to 2004

\begin{tabular}{cccc}
\hline Year & $\begin{array}{c}\text { Annual Total } \\
\text { Expenditure of visitors } \\
\text { (SGD) }\end{array}$ & $\begin{array}{c}\text { Number of } \\
\text { incoming flights } \\
\text { (per week) }\end{array}$ & $\begin{array}{c}\text { Number of seats on } \\
\text { incoming flights (per week) }\end{array}$ \\
\hline $\mathbf{2 0 0 2}$ & $5,425,800$ & 1,569 & 417,952 \\
$\mathbf{2 0 0 3}$ & $4,315,600$ & 1,490 & 408,606 \\
$\mathbf{2 0 0 4}$ & $6,278,300$ & 1,728 & 452,221 \\
\hline
\end{tabular}

Source: Singapore Tourism Board, “Annual Report on Tourism Statistics” (2002-2004)

Table 5: Hotel Statistics, First to Fourth Quarter 2003

\begin{tabular}{lcccc}
\hline Quarter & $\begin{array}{c}\text { Average } \\
\text { occupancy rate } \\
\text { (\%) }\end{array}$ & $\begin{array}{c}\text { Average room } \\
\text { rate (SGD) }\end{array}$ & $\begin{array}{c}\text { Hotel room } \\
\text { revenue (million } \\
\text { SGD) }\end{array}$ & $\begin{array}{c}\text { Food and } \\
\text { beverage revenue } \\
\text { million SGD) }\end{array}$ \\
\hline First & 72 & 121.5 & 221.7 & 374.3 \\
Second & 42.1 & 106.7 & 92.6 & 284.8 \\
Third & 73.6 & 107.3 & 191.8 & 357.7 \\
Fourth & 76.9 & 117.4 & 220.2 & 399.6 \\
\hline Source: & Economic Survey of & Singapore 2003, Singapore & Department & of Statistics, \\
& http://www.Singstat.gov.sg/ (Accessed April 15, 2012) & &
\end{tabular}

The hospitality industry had to resort to cutting budgets, which led to a steep plunge in the number of employed in the service sector. Out of a total of 12,100 made unemployed, hotels and restaurants went through the biggest cut, that being 5,800 employees. The breakdown of total job losses showed $47 \%$ in the service sector, $28 \%$ in construction, and 25\% in manufacturing. Additionally, transactions in the retail sector were dropped by $50 \%$.

The private property volume transactions for condominiums and private property price index are also good proxies on the impact of the economy from SARS. Based on quarterly figures between 2002 and 2004, the volume transactions dipped to a low in the first quarter of 2003. Also, there was a corresponding decline in the price index. Transactions recovered steadily by the third quarter boosted by confidence in market sentiments (See Figure 5). The STI and private property price index seemed to display fairly similar trends, albeit with some observed lag. Note also that there is 
a lagged effect of consumer's deferred purchases after the outbreak of SARS in Singapore.

Figure 5: Private Property Volume Transactions (Condominiums), Private Property Price Index (Quarterly 2002-2004)

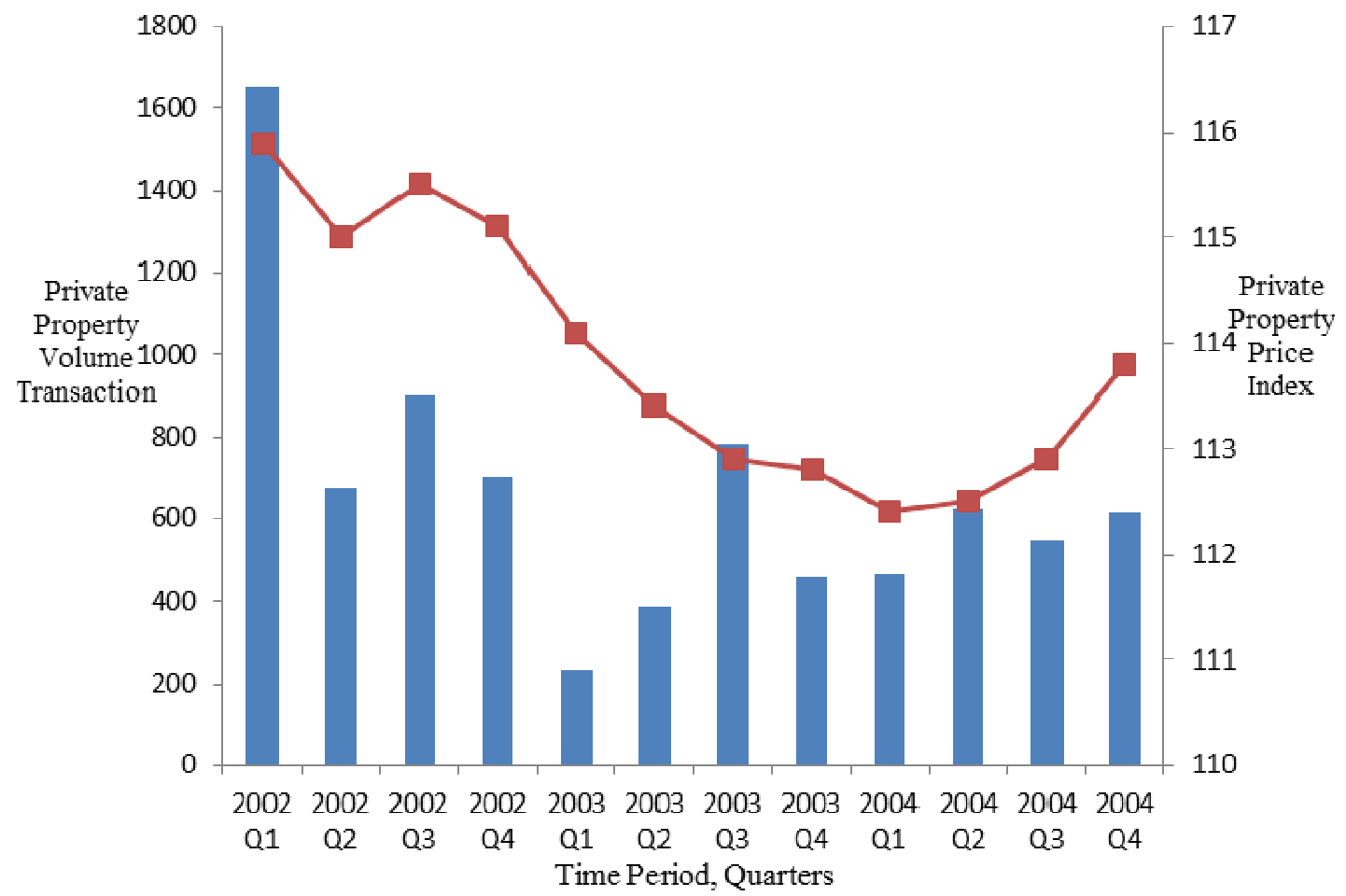

Source: Singapore Real Estate, available at http://www.singaporerealestate.info/blog/propertytools/spsf-chart-d09-10/ (Accessed April 15, 2012),

http://www.h88.com.sg/property_stats/property_price_index.php (Accessed April 15, 2012)

Demand creates its own supply. Therefore, a fall in demand of goods and services is likely to bring about a fall in the supply of such goods and services. Also, the loss of consumer and business confidence would reduce the level of aggregate demand. These effects were observed as the manufacturing industry experienced supply chain disruptions as the Singaporean economy and employment market continued to weaken. Singapore was taken off the WHO's list of SARS affected countries on $31^{\text {st }}$ May 2003 - one of the first countries to be removed from the list. With the "fear-factor" managed, normal daily activities slowly resumed. SARS affected industries and sectors started to show signs of recovery towards the end of 
the second quarter in 2003. A more comprehensive analysis of the economic costs of SARS will need to consider the direct impact on consumer spending and indirect repercussions of the shock on trade and investment (Asian Development Bank Outlook, 2003). The economic costs from a global disease, such as SARS, go beyond the immediate impacts incurred in the affected sectors of disease-inflicted countries. This is not just because the disease spreads quickly across countries through networks related to global travel, but also because any economic shocks to one country spread quickly to other countries through the increased trade and financial linkages associated with globalization. However, just calculating the number of cancelled tourist trips, the declines in retail trade, and some of the factors discussed earlier do not provide a complete picture of the impact of SARS. This is because there are close linkages within economies, across sectors, and across economies in both international trade and international capital flows. Thus, analyzing the tourism sector alone may not be sufficient in analyzing the overall financial impact of SARS. SARS inflicted a heavy toll on businesses and immediately impacted severely the viability of business. Businesses lost employees for long periods of time due to factors such as illness, the need to care for family members and fear of infection at work, or retrenchment. As the workforce shrunk due to absenteeism, business operations, for example supply chain, flow of goods worldwide and provision of services, were all affected both locally and internationally. In terms of retrenchment, the job prospects of employees in affected companies appeared miserable. A survey performed during the SARS period showed that the jobless rate increased more than 5.5\%, the highest for the last decade in Singapore (Ministry of Manpower, Singapore, 2003). In absolute numbers, overall employment diminished by 25,963 in the second quarter of 2003, the largest quarterly decline since the mid-1980s recession. Unlike previous retrenchment that affected mainly blue-collar labor, SARS also affected white-collar employees too. The implementation of workplace SARS control measures added to operational and administrative costs. For example, the policy of temperature taking was implemented at workplaces in the private sector. Numerous private establishments installed thermal-scanners in their entrances from day one. However, such 
precautionary measures were necessary to contain the disease. This helped to restore business confidence and investment potential (a lower level of investments will lead to slower capital growth). But the reduction in an economy's capacity may linger on for a few quarters before it is restored to pre-SARS levels. The loss of productive working days from quarantine, and implementation costs incurred to monitor movements of employees contributed to the reduction in the aggregate supply front. Some of these economic effects may have worsened the public health situation if strategic planning was not in place.

\section{Healthcare System Impact}

SARS reduced levels of service and care in Singapore's healthcare system as the system mobilized its medical resources to deal with the SARS epidemic. The influx of influenza patients to hospitals and clinics crowded out many other patients with less urgent medical problems for treatment. This particularly affected those seeking elective operations that had to be postponed until the epidemic ended in Singapore. SARS also severely impacted Singapore's healthcare manpower. During the peak of SARS from mid-March 2003 to early April 2003, there was a shortage of medical and nursing professionals because 1) the demand for care of influenza patients substantially increased, and 2) the supply of healthcare manpower decreased as somewhere also affected by the epidemic. Like other business sectors, hospitals, clinics and other public health providers also faced a high staff-absenteeism rate and encountered difficulties in maintaining normal operations. This resulted in a further reduction in the level of service capacity.

\section{Psychosocial Impact}

Psychosocial impact from SARS was mainly caused by limited medical knowledge of SARS when it began its insidious spread in Singapore. Such uncertainty of contracting a highly contagious disease actually deteriorated the fear of security breaches, and the panic of overexposure (Tan, 2006). Responding to the uncertainty of disease transmission, the Singapore government instituted many draconian public policies, such as social distancing, quarantine and isolation, as risk 
mitigating measures. All of these control measures created an instinctive withdrawal from society for the general population. This brought about a behavior which resulted in the public avoiding crowds and public places with human interaction. On 24 March 2003, the MOH invoked the Infectious Disease Act (IDA) to isolate all those who had been exposed to SARS patients. After IDA was invoked, on 25 March 2003, schools and non-essential public places were closed. Public events were cancelled to prevent close contact in crowds. Singaporeans with contact history were asked to stay home for a period of time to prevent transmission. Harsh penalties, such as hefty fines of more than USD 4,000 or imprisonment, were imposed on those who defied quarantine orders. In a drastic move reminiscent of a police state, closed-circuit cameras were installed in the houses of those ordered to stay home to monitor their compliance with the quarantine order (ABC News Online, 2003). At the height of SARS, 12,194 suspected cases were ordered to stay home, all of whom were monitored either by cameras or in less severe cases, by telephone calls. Quarantine, regardless of its effectiveness, received strong criticism from the general public during the outbreak of SARS due to the invasive nature of that measure (Duncanson, 2003). Impact of social distancing remains unclear, but WHO has recommended such control measures depending on the severity of the epidemic, risk groups affected and epidemiology of transmission (WHO, 2005). Singapore's MOH advocated the practice of social distancing during the outbreak of SARS. The sole intention of social distancing was to limit physical interactions and close contact in public areas to slow the rate of disease transmission. Additionally, social distancing measures in particular have a psychological impact. The practice of social distancing led to a social setback in businesses that suffered economic losses as a result (Duncanson, 2003). The psychological impact of SARS is longer lasting. The most immediate and tragic impact was the loss of loved ones. 


\subsection{Singapore’s Risk Mitigating Measures}

In this section, we detail Singapore's command structure, legal framework in fighting SARS, as well as risk mitigating measures in economic, healthcare, and psychosocial perspectives.

\subsubsection{Command Structure and Legal Framework}

One of the most important lessons the Singapore government learned from the SARS epidemic was the crucial role played by the bureaucracy in disaster management. The bureaucratic structure in place then was severely inadequate in terms of handling a situation that was both fluid and unprecedented; indeed, fighting SARS required more than a medical approach because resources had to be drawn from agencies other than the MOH. Accordingly, a three-tiered national control structure was created in response to SARS - these tiers were individually represented by the Inter-Ministerial Committee (IMC), the Core Executive Group (CEG) and the Inter-Ministry SARS Operations Committee (IMOC) (Tay and Mui, 2004). The nine-member IMC was chaired by the Minister of Home Affairs (MHA) and it fulfilled three major functions: 1) to develop strategic decisions, 2) to approve these major decisions, and 3) to implement control measures (Figure 6). ${ }^{7}$

Figure 6: Singapore's Organizational Structure for Fighting SARS

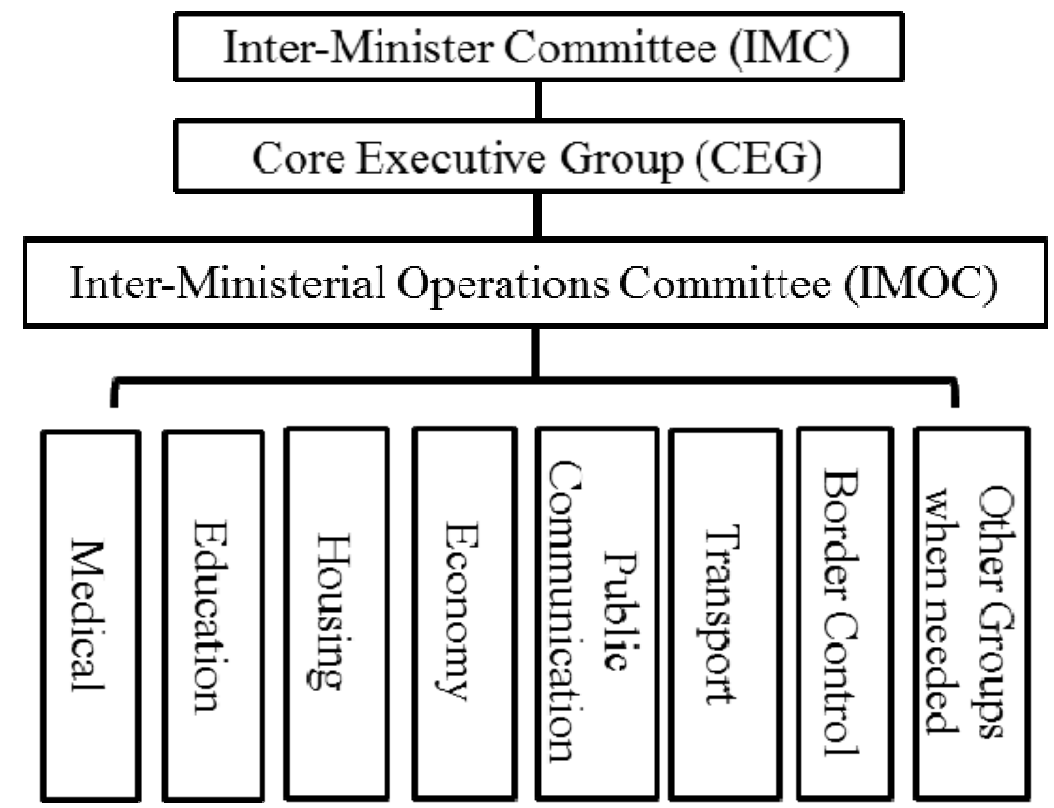

Source: Adapted from Tay and Mui (2004, p. 35). 
Notably, the IMC also played the role of an interagency coordinator overseeing the activities of other ministries and their subsidiaries. On 7 April 2003 (five weeks after the first case of SARS was reported), the CEG and a ministerial committee was formed. The CEG was chaired by the Permanent Secretary of Home Affairs and consisted of elements from three other ministries: the MOH, the Ministry of Defense (MOD) and the Ministry of Foreign Affairs (MFA). In particular, the role of the CEG was to manage the SARS epidemic by directing valuable resources to key areas. The IMOC, meanwhile, was seminal in carrying out health control measures issued by the IMC (Figure 7). The MOH, at the operational layer, formed an Operations Group responsible for the planning and coordination of health services, and operation in peacetime. During SARS, it commanded and controlled all medical resources and served as the main operational linkage between the $\mathrm{MOH}$ and all the healthcare providers.

\section{Figure 7: Chronology of Singapore’s Control Measures}

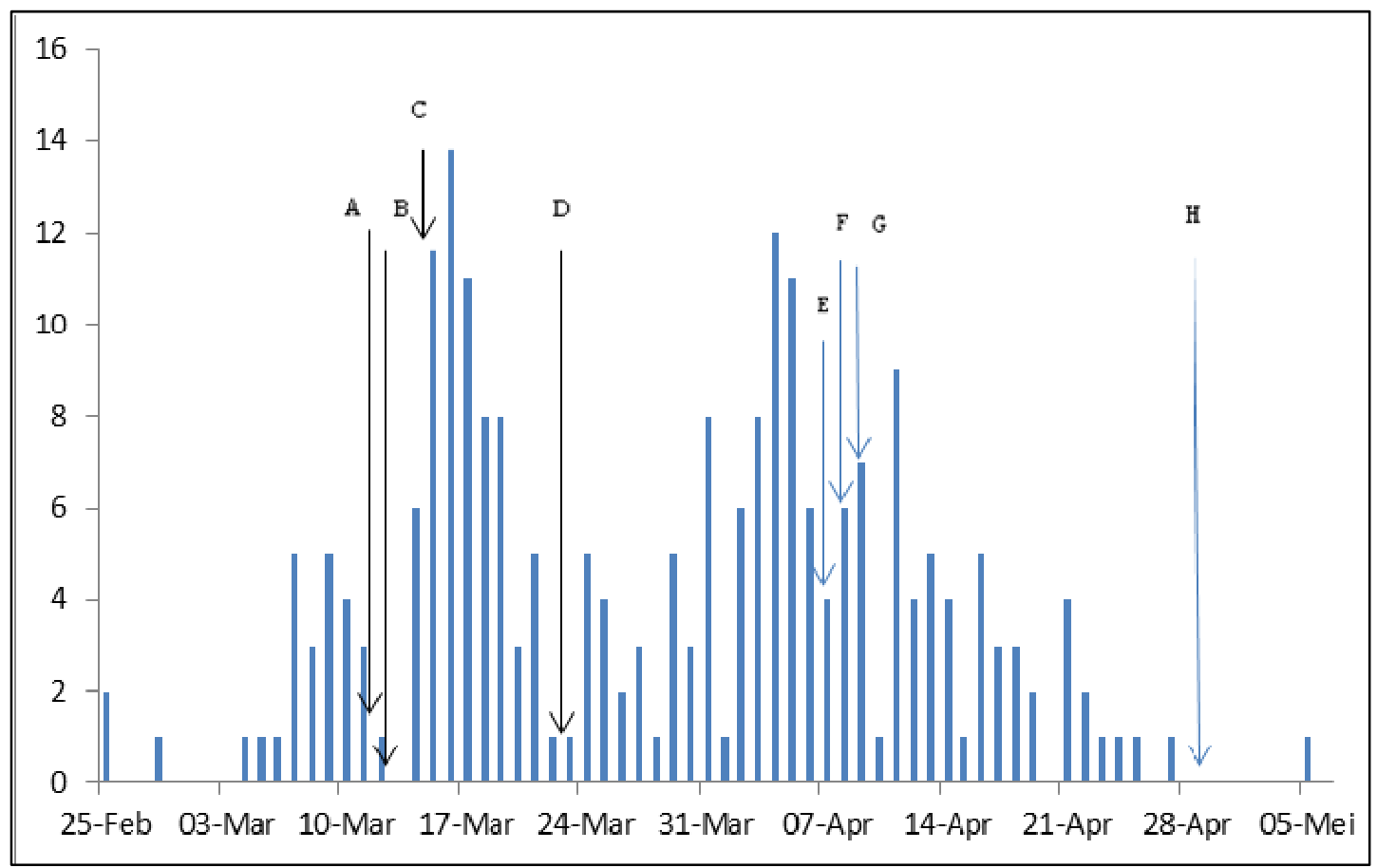

Note: A: (13 March) WHO's global alert on SARS, MOH's directive to isolate all cases of atypical pneumonia; B: (14 March) MOH advisory to the public to avoid travel to SARSaffected countries; C: (16 March) triage at Emergency Departments to separate out febrile patients from other types of patients and unprotected staff and members of the public; D: (22 March) Tan Tock Seng Hospital designated as the SARS hospital. Home quarantine and daily telephone surveillance of contacts with suspected SARS cases; E: (7 April) 
formation of the Ministerial Committee on SARS chaired by the Minister for Home Affairs; F: (8 April) MOH directive under the Private Hospitals and Medical Clinics Act requiring all hospitals and nursing homes to ensure effective implementation of detailed procedures on triage, isolation, use of personal protective equipment and infection control; G: (9 April) passengers of all inbound flights required to complete a Health Declaration Card. Thermal scanners deployed at airport; H: (30 April) Mandatory temperature screening of children in schools.

Source: Tan (2006)

On 15 March 2003, when the epidemiological nature of SARS was still unclear, the $\mathrm{MOH}$ initiated a SARS taskforce to look into the mysterious strain. Only two days later, after more SARS cases were reported and a better epidemiological understanding of the strain was developed, the Singapore government swiftly declared SARS a notifiable disease under the Infectious Disease Act (IDA) (Ministry of Health, 2003b). In the case of a broad outbreak, IDA made it legally permissible to enforce mandatory health examination and treatment, exchange of medical information and cooperation between healthcare providers and the $\mathrm{MOH}$, and the quarantine and isolation of SARS patients (Infectious Disease Act, 2003). In particular, the government amended the IDA on 24 April 2003 requiring all those who had come into contact with SARS patients to remain indoors or report immediately to designated medical institutions for quarantine (Ministry of Health, Singapore, 2003b). Asa legacy of Singapore’s British colonial past, the Singapore legislature is unique and well-known for passing laws in a swift and efficient manner. The uniqueness in Singapore's legal framework allows Singapore to swiftly amend the IDA during health crises to suit volatile conditions, for instance when more epidemiological cases were uncovered and the virus was better understood. All in all, the IDA played an adaptive role in terms of facilitating a swift response to the outbreak of this particular epidemic. On 22 March 2003, the CEG designated the restructured public hospital - Tan Tock Seng Hospital (TTSH) as the SARS hospital (James, et al. 2006; Tan, 2006). That is, once a suspected SARS patient was detected at a local clinic or emergency department, he or she would then be transferred to TTSH immediately for further evaluation and monitoring. The national healthcare system prioritized life-saving resources such as medicine and medical equipment to allocate manpower and protective equipment to the TTSH. To ease the flu-like patient influx into the TTSH, the government diverted non-flu 
patients away from TTSH so that the sudden surge in the number of flu cases at TTSH did not paralyze its service delivery.

\subsubsection{Economic Measures}

The full impact of SARS on the economy by and large depended on how quickly SARS was contained, as well as the course of the SARS outbreak in the region and beyond. To mitigate SARS impact on Singapore's economy, the government took every precaution and spared no effort to contain the SARS outbreak in Singapore. Two aspects of SARS warranted government intervention to mitigate economic impact. First, the information that needs to be collected and disseminated to effectively assess SARS displays the characteristics of public good. Second, there are negative externalities related to contagious diseases in the sense that they affect third parties in market transactions. Public good and negative externalities are typical areas where government action is needed (Fan, 2003). There are three major factors which can explain why some economies are more vulnerable and susceptible to the effect of SARS than others (Asian Development Bank Outlook, 2003). These factors are structural issues (e.g. shares of tourism in GDP and the composition of consumer spending), initial consumer sentiments, and government responses. As the research shows, the Singapore government implemented a USD 132 million (SGD 231 million in 2003) SARS relief package to reduce the costs for tourism operators and its auxiliary services. On the other hand, an economic relief package worth USD 131m (SGD 230m) was created to aid businesses hit by SARS. ${ }^{8}$ In addition, the government incurred USD\$109m (SGD 192m) in direct operating expenditure related to SARS, and committed another USD 60m (SGD105m) development expenditure of hospitals for additional isolation rooms and medical facilities to treat SARS and other infectious diseases. The government's economic incentives worked when seeking cooperation of other healthcare providers (such as public hospitals and local clinics) so that they would absorb additional cases of non-flu illnesses.

To help SARS affected firms tide over the plight and minimize job losses, Singapore's National Wage Council widely consulted the private sector, and recommended SARS-struck companies adopt temporary cost-cutting measures to 
save jobs. ${ }^{9}$ The measures adopted by the private sector included the implementation of a shorter working-week, temporary lay-offs and the arrangement for workers to take leave or undergo skills training and upgrading provided by the Ministry of Manpower and associated agencies. When these measures failed to preserve jobs, the last resort was temporary wage cuts.

\subsubsection{Public Health Control Measures}

\section{Surveillance and Reporting}

Surveillance and reporting is critical in combating pandemics because it serves to provide early warning and even detection of impending outbreaks. The surveillance process involves looking out for possible virulent strains and disease patterns within a country's borders as well as at major border-crossings (Jebara, 2004; Ansell, et al. 2010; Narain and Bhatia, 2010). When SARS first surfaced, the nature of this virus was largely unknown. As a consequence, health authorities worldwide were mostly unable to detect and monitor suspected cases. Health authorities in Singapore encountered this same problem. But with the aid of WHO technical advisors, Singapore managed to establish in a timely manner identification and reporting procedures. Furthermore, the $\mathrm{MOH}$ also expanded the WHO's definitions for suspected cases of SARS (to include any healthcare workers with fever and/or respiratory symptoms) in order to widen the surveillance net (Goh, et al. 2006). As the pace of SARS transmission quickened, the Singapore Parliament amended the IDA on 25 April 2003 requiring all suspected SARS cases to be reported to the $\mathrm{MOH}$ within 24 hours from the time of diagnosis.

Although these control measures were laudable, SARS also exposed the weaknesses of Singapore's fragmented epidemiological surveillance and reporting systems (Goh, et al. 2006). As a major part of lesson-drawing in the post-SARS era, a number of novel surveillance measures were introduced to integrate epidemiological data and to identify the emergence of a new virulent strain faster. One of the most notable was the establishment of an Infectious Disease Alert and Clinical Database system to integrate critical clinical, laboratory and contact tracing information. Today, the surveillance system has four major operational components 
that include community surveillance, laboratory surveillance, veterinary surveillance, external surveillance, and hospital surveillance.

\section{Hospital Infection Control}

To limit the risk of transmission in healthcare institutions once the SARS epidemic had broken out, the $\mathrm{MOH}$ implemented a series of stringent infectioncontrol measures that all healthcare workers (HCWs) and visitors to hospitals visitors had to adhere to. The use of personal protective equipment (PPE) ${ }^{10}$ was made compulsory. Visitors to public hospitals were barred from those areas where transmission and contraction were most likely. The movements of HCWs in public hospitals were also heavily proscribed. Unfortunately, except for TTSH, these critical measures were not enforced in all healthcare sectors until 8 April 2003, and this oversight resulted in a number of intra-hospital infections (Goh, et al. 2006). In addition, the policy of restricting the movements of HCWs and visitors to hospitals was taken further. More specifically, their movements between hospitals were now restricted. Patient movement between hospitals, meanwhile, was strictly restricted to medical transfers. The number of visitors to hospitals was also limited and their particulars recorded during each visit. It is also important to point out that these somewhat draconian control measures required strong public support and cooperation. Indeed, their implementation would not have been successful had these two elements been missing.

\section{Public Education and Communication}

Public education and communication are two indispensable components in health crisis management (Reynolds and Seeger, 2005; Reddy, et al. 2009). Communication difficulties are prone to complicate the challenge, especially when there is no established, high-status organization that can act as a hub for information collation and dissemination. Therefore, it is necessary to disseminate essential information to the targeted population in a transparent manner. During the SARS outbreak, the $\mathrm{MOH}$ practiced a high degree of transparency when it shared 
information with the public. Indeed, the clear and distinct messages from the $\mathrm{MOH}$ contributed significantly to lowering the risk of public panic.

The MOH worked closely with the media to provide regular, timely updates and health advisories. This information was communicated to the public through every possible medium. In addition to the media (e.g. TV and radio), information pamphlets were distributed to every household and the $\mathrm{MOH}$ website provided constant updates and health advisories to the general public. Notably, a government information channel dedicated to providing timely updates was created on the same day - 13 March 2003 - when the WHO issued a global alert. A dedicated TV Channel called the SARS Channel was launched to broadcast information on the symptoms and transmission mechanisms of the virus (James, et al. 2006). The importance of social responsibility and personal hygiene was a frequent message heard throughout the SARS epidemic. As an example, when Tan Tock Seng Hospital was designated as the SARS hospital at the peak of SARS epidemics, the government undertook many efforts in public communication and education to seek cooperation and support from other healthcare providers, such as public hospitals and local clinics, so that they would absorb the additional cases of non-flu illnesses. Many organizations displayed prominent signs in front of their building entrances that reminded their staff as well as visitors to be socially responsible. School children were instructed to wash their hands and take their body temperature regularly. The public was told to wear masks and postpone non-essential travel to other countries.

\section{Social Distancing}

The $\mathrm{MOH}$ advocated the practice of social distancing during the outbreak of SARS. The sole intention of social distancing was of course to limit physical interactions and close contact in public areas thereby slowing the rate of transmission. As a result, all pre-school centers, after-school centers, primary and secondary schools, and junior colleges were closed from 27 March to 6 April 2003. School children who had stricken siblings were advised to stay home for at least 10 days. Moreover, students who showed flu-like symptoms or had travelled to other affected 
countries were automatically granted a 7-day Leave of Absence and home-based learning program were instituted for those affected. Extracurricular activities were also scaled down to minimize social contact. Meanwhile, the MOH also advised businesses to adopt social distancing measures such as allowing staff to work from home and using split-team arrangements. Those who were most at higher risk of developing complications if stricken were moved and removed from frontline work to other areas where they were less likely to contract the virus. As mentioned earlier, the practice of social distancing also drew strong criticisms from those businesses that suffered economic losses as a result. Apart from providing economic compensation, measures to mitigate psychosocial impacts are also important.

\subsubsection{Psychosocial Measures}

The government's measures of public health control, as mentioned above, drew strong criticisms from businesses and the public during the outbreak of SARS due to the invasive nature of those actions. Besides these, the economic slowdown affected overall employment and personal income. Some households required financial assistance. In response to the public complaints, authorities in Singapore provided economic assistance to those individuals and businesses who had been affected by home quarantine orders through a "Home Quarantine Order Allowance Scheme" (Tay and Mui, 2004; Teo, et al. 2005).

At the same time, the $\mathrm{MOH}$ worked together with various ministerial authorities to provide essential social services to those affected by the quarantine order. For example, housing was offered to those who were unable to stay in their own homes (because of the presence of family members) during their quarantine, ambulance services were freely provided by the Singapore Civil Defence Force to those undergoing quarantine at home to visit their doctors, as well as high-tech communication gadgets such as webcams, for those undergoing quarantine to stay in touch with relatives and friends. Impacts on social welfare in large part relate to economic outlook, especially in the area of consumption patterns. All these risk mitigating measures were not only effective in containing the epidemic, but also valid for implications in disaster risk management. 


\section{Implications for Practice and Research}

In this section, we draw on the lesson-learning from Singapore's experience in fighting the SARS epidemic, and discuss implications for future practice and research in disaster risk management. The implications are explained in four aspects: staying vigilant at the community level, remaining flexible in a national command structure, demand for surge capacity, and collaborative governance at regional level.

\section{Staying Vigilant at the Community Level}

It remains questionable that Singapore's draconian health control measures may not be applicable or replicable in other countries, for example setting a camera to monitor the public's compliance during home quarantine. The evidence suggests that draconian government measures, such as quarantine and travel restrictions, are less effective than voluntary measures (such as good personal hygiene and voluntarily wearing of respiratory masks), especially over the long term (Bruine, et al. 2007). However, reminding the public to maintain a high level of vigilance and advocate individual social responsibility can be a persuasion tactic by an authority to influence and pressure, but not to force individuals or groups into complicity with a policy (Aledort, et al. 2007; Aimone, 2010; Barrett, 2007). Therefore, promoting social responsibility is crucial in terms of slowing the pace of infection through good personal hygiene and respiratory etiquette in all settings.

To achieve this goal, public education and risk communication are two indispensable components in health crisis management (Reddy, et al. 2009; Reynolds and Seeger, 2005). The community must be aware of the nature and scope of disasters. They have to be educated on the importance of emergency preparedness and involvement in exercises, training and physical preparations. At the community level, institutions and capacities are developed and strengthened which in turn systematically contribute to vigilance against potential risks.

This is best illustrated in the Singapore government's communication strategy to manage public fear and panic during the outbreak of SARS (Menon and Goh, 2005). Throughout the epidemic, the Singapore government relentlessly raised the level of 
vigilance of personal hygiene and awareness of social responsibility. This, in large part, has to rely on public education and risk communication. To effectively disseminate the idea of vigilance across the public, political leaders were seen as doing and initiating a series of countermeasures to reassure the public. By showing the people that government leaders practiced what they preached, the examples served to naturalize and legitimize the public discourse of social responsibility for all Singaporean citizens (Lai, 2010).

The need to stay vigilant is never overemphasized, but being vigilant does not equate to a panacea that ensures all government agencies work together. To be well prepared for the unexpected, we need a clear and swift national command structure that can flexibly respond to, and even more promptly than in the case of disease transmission, the changing situation.

\section{Remaining Flexible in a National Command Structure}

All local agencies responding to an emergency must work within a unified national command structure to coordinate multi-agency efforts in emergency response and management of disasters. On top of facilitating close inter-agency coordination, the strength of this flexible structure is in its ability to ensure a swift response to an epidemic outbreak by implementing risk mitigating measures more effectively and efficiently. Structural flexibility involves swift deployment of forces to mitigate the incident at the tactical level, and to provide expert advice at the operational level, in order to minimize damage to lives and property. Among other things, the flexibility endemic to this command structure facilitates the building of trust between the state and its people (Lai, 2009). This in turn ensures that government measures are quickly accepted by the general public.

As shown in this paper, the $\mathrm{MOH}$ has been entrusted by the Singapore government and pre-designated to be the Incident Manager for public health emergencies. When a sudden incident involves public health or the loss of lives on a large scale, the $\mathrm{MOH}$ is responsible for planning, coordinating and implementing an assortment of disease control programs and activities. During the outbreak of SARS, 
the Singapore government established a national command and control structure that was able to adapt to rapidly changing circumstances that stemmed from the outbreak.

Specifically, the MOH set up a taskforce within that ministry even when the definition of SARS remained unclear. As more SARS cases were uncovered and better epidemiological information became available, the government quickly created the Inter-Ministerial Committee (IMC) and Core Executive Group (CEG) - both of which were instrumental in the design and implementation of all risk mitigating measures - to coordinate the operation to combat the outbreak (Pereira, 2008). While this overarching governance structure is more or less standard worldwide ('t Hart, et al. 1993; La Porte, 2007), the case of Singapore is unique in that the citystate was able to overcome bureaucratic inertia and adapt this governance structure.

From Singapore's experiences during the SARS crisis, we have learnt that the strength of a national command structure lies in its flexibility to link relevant ministries on the same platform. These linkages ensure a timely, coordinated response and service delivery. Having a flexible structure was not the only reason behind the successful defeat of SARS. In Singapore's case, we also notice the success of containing an uncertain, high-impact disaster has to rely on surge capacity.

\section{The Demand for Surge Capacity}

In the context of this paper, surge capacity refers to the ability to mobilize resources (such as PPEs, vaccines and HCWs) to combat the outbreak of a pandemic. Singapore's response to SARS in 2003 illustrates the importance of being able to increase surge capacity swiftly to deal with an infectious disease outbreak. In the Asia Pacific region, this problem continues to hamper many countries' ability to combat infectious diseases (Putthasri, et al. 2009). For many public health organizations in Asia, it is a matter of fact that they are unable to deal with pandemics because the resources to do so are simply absent (Balkhy, 2008; Hanvoravongchai, et al. 2010; Lai, 2012b; Oshitani, et al. 2008). Meanwhile, there are evidences which suggest that surge capacity alone is not the full answer. For example, during the SARS outbreak, abundant resources contribute an important but not all-encompassing element in the fight against these pandemics. As it turned out, 
when different stakeholders brought to the task-at-hand their unique skill sets and resources, they actually complicated the fight due to their lack of synergy. In fact, abundant resources without synergy might even undermine collaborative efforts. Therefore, it is essential that the ability to link up various stakeholders must be complemented by some type of synergy between them. Such ability can be enhanced through close collaboration. This brings us to the third implication for disaster management: collaborative governance at regional level.

\section{Collaborative Governance at Regional Level}

The trans-boundary nature of the disasters calls for a planned and coordinated approach towards disaster response for efficient rescue and relief operations (Lai, et al. 2009; Lai, 2012a). Combating epidemics requires multiple states and government agencies to work together in close (Shalala, 1997; Webby and Webster, 2003). Therefore, it is clear that collaborative capacity of various stakeholders is central to the fight against transboundary communicable diseases (Lai, 2011; Lai, 2012b; Leung and Nicoll, 2010; Voo and Capps, 2010). While member states that are of advanced economic development typically lead such efforts, the inclusion of other developing countries, non-traditional agencies, and organizations (including nongovernmental ones) is necessary and ultimately, inevitable. Indeed, major countermeasures such as border control and surveillance are often made possible with the aid of regional collaboration. Take the Association of Southeast Asian Nations (ASEAN) as an example.

ASEAN countries take regional, national and sub-national approaches to disaster risk management (Lai, et al. 2009). The ASEAN Committee on Disaster Risk Management (ACDM) was established in 2003 and tasked with the coordination and implementation of regional activities on disaster management. The Committee has cooperated with United Nations bodies such as the United Nations International Strategy for Disaster Reduction (UNISDR) and the United Nations Office for the Coordination of Humanitarian Affairs (UNOCHA). The ASEAN Agreement on Disaster Management and Emergency Response (AADMER) provides a comprehensive regional framework to strengthen preventive, monitoring and 
mitigation measures to reduce disaster losses in the region. In recent years, Singapore has been active in providing training and education for disaster managers from neighboring countries. Singapore has an ongoing exchange program with a number of Asia Pacific nations and Europe. For example, to partner with APEC to increase emergency preparedness in the Asia-Pacific region, Singapore's SCDF provides short-term courses on disaster management in the Civil Defence Academy (Asia Pacific Economic Cooperation, 2011).

\section{Conclusions}

The world today is far more inter-connected than ever before. International travel, transnational trade, and cross-border migration have drastically increased as a consequence of globalization. No country is spared from being influenced directly or indirectly by disasters. Singapore is no exception. Singapore is vulnerable to both natural and man-made disasters alongside its remarkable economic growth. In response, the Singapore government adopts an approach of Whole-of-Government Integrated Risk Management, a concerted, coordinated effort based on a total national response.

We have witnessed in the case study Singapore's all-hazard management framework with specific references to the SARS epidemic. In fighting SARS, Singapore's health authority was responsive enough to swing into action when they realized that the existing bureaucratic structure was inadequate in terms of facilitating close cooperation between various key government agencies to tackle the health crisis on hand. Therefore, a command structure was swiftly established. The presence of a flexible command structure, the way and the extent it was utilized, explains how well an epidemic was successfully contained. Flexibility actually enhanced organizational capacities by making organizations more efficient under certain conditions.

Epidemic control measures such as surveillance, social distancing, and quarantine require widespread support from the general public for them to be 
effective. Singapore's experiences with SARS strongly suggest that risk mitigating measures can be effective only when a range of partners and stakeholders (such as government ministries, non-profit organizations, and grass-roots communities) become adequately involved. This is also critical to disaster risk management. Whether all of these aspects are transferrable elsewhere needs to be assessed in future research. Nonetheless, this unique discipline certainly has helped Singapore come out of public health crises on a regular basis. Singapore's response to the outbreak of SARS offers valuable insights into the kinds approaches needed to combat future pandemics, especially in Southeast Asia.

Acknowledgement: the authors would like to thank the Economic Research Institute for ASEAN and East Asia (ERIA) to initiate this meaningful research project, and four commentators - Professor Yasuyuki Sawada (Tokyo University), Professor Chan Ngai Weng (University Sains Malaysia), Dr. Sothea Oum (ERIA), Mr. Zhou Yansheng (SCDF) and all participants in ERIA's two workshops, for their insightful comments for an earlier draft of this paper.

\section{References}

ABC News Online (2003), Singapore Imposes Quarantine to Stop SARS Spreading. ABC News [online] 25 March 2003. http://www.abc.net.au/news/2003-0325/singapore-imposes-quarantine-to-stop-sars-spreading/1823362 (accessed June 29, 2012).

Ansell, C., A. Boin, and A. Keller (2010), 'Managing Transboundary Crises: Identifying the Building Blocks of an Effective Response System', Journal of Contingencies and Crisis Management 18(4), pp.195-207.

Asian Conference on Disaster Reduction (2010), HFA Implementation Review for ACDR 2010. Kobe, Japan. ADRC [online] http://www.adrc.asia/acdr/2010kobe/documents/HFA/Singapore.pdf (accessed June 29, 2012).

Asian Development Bank Outlook (2003), Asian Development Outlook 2003 Update. Manila: ADB. http://www.scribd.com/doc/49451493/Asian-DevelopmentOutlook-2003-Update (accessed June 29, 2012) 
Asian Disaster Reduction Center (2005), ADRC Country Report, 2005. ADRC [online]. http://www.adrc.asia/countryreport/SGP/2005/english.pdf (accessed June 29, 2012).

Asia Pacific Economic Cooperation (2011), APEC Partners with Singapore on Disaster Management. Singapore: APEC. http://www.apec.org/Press/NewsReleases/2011/0401_disaster.aspx (accessed June 29, 2012).

Attorney-General's Chambers (2003), Impact of SARS on the Economy, Singapore Government. AGC [online]. http://statutes.agc.gov.sg/aol/search/display/view. w3p;page $=0$; query $=$ CompId\%3A2eff60ec-1a14-4368-a0c503d5bf324d02\%20ValidTime\%3A20120307000000\%20TransactionTime\%3 A20120307000000; rec $=0$ (accessed June 29, 2012).

Balkhy, H.(2008),'Avian Influenza: the Tip of the Iceberg', Annals of Thoracic Medicine 3(4), pp.154-57.

Bruine, de B.W., B. Fischhoff, L. Brilliant, and D. Caruso (2006), 'Expert Judgments of Pandemic Risks', Global Public Health 1(20), pp.1-16.

Centers for Disease Control and Prevention (2003, 9 May), 'Editorial Note to: Y. S. Leo et al., Severe Acute Respiratory Syndrome - Singapore, 2003', Morbidity and Mortality Weekly Report, 52(18), 411. http://www.cdc.gov/mmwr/PDF/wk/mm5218.pdf (accessed 8 May, 2012)

Duncanson, J. (2003), How Singapore Avoided WHO Advisory. Toronto Star [online] 25 April 2003. http://www.singapore-window.org/sw03/030425ts.htm (accessed 8 May, 2012)

Emmanuel, S. C. (2000), 'Impact to Lung Health of Haze from Forest Fires: The Singapore Experience’, Respirology 5(2), pp.175-82.

Fan, E. X. (2003), 'SARS: Economic Impacts and Implications,' ERD Policy Brief No. 15, Manila: Asia Development Bank.

Global Facility for Disaster Reduction and Recovery (2011), 'Advancing Disaster Risk Financing and Insurance in ASEAN Countries: Framework and Options for Implementation', Global Facility for Disaster Reduction and Recovery, 2011. GFDRR [online]. http://www.gfdrr.org/gfdrr/sites/gfdrr.org/files/DRFI_ASEAN_DRFI_draft_r eport(October\%2030,\%202011).pdf (accessed on Dec 8, 2011)

Goh, C. L. (2004), ‘A New World Now after Hotel Collapse,’ The Straits Times 15 March 2004.

Goh, K. T., J. Cutter, B. H. Heng, S. Ma, B. K.W. Koh, C. Kwok, C. M. Toh, and S.K. Chew (2006), 'Epidemiology and Control of SARS in Singapore,' Ann Acad Med Singapore 35, pp.301-16.

Hanvoravongchai, P., W. Adisasmito, N. C. Pham, A. de Conseil, J. de Sa , R. Krumkamp, S. Mounier-Jack, B. Phommasack, W. Putthasri, C. S. Shih, S. Touch, and R. Coker (2010), 'Pandemic Influenza Preparedness and Health 
Systems Challenges in Asia: Results from Rapid Analyses in 6 Asian Countries,' BMC Public Health, 10, 322.

Henderson, J. (2003), 'Managing a Health-related Crisis: SARS in Singapore,' Journal of Vacation Marketing 10(1), pp.67-77.

Hart, P., U. Rosenthal, and A. Kouzmin (1993), 'Crisis Decision Making: The Centralization Thesis Revisited,' Administration and Society 25(1), pp.12-45.

Infectious Disease Act (2003), 'Infectious Disease Act, Chapter 137 (Singapore)', Singapore Government. AGC [online]. http://statutes.agc.gov.sg (accessed 23 April 2012).

James, L., N. Shindo, J. Cutter, S. Ma, and S. K. Chew (2006), 'Public Health Measures Implemented during the SARS Outbreak in Singapore, 2003', Public Health 120, pp.20-26.

Jebara, K. B. (2004), 'Surveillance, Detection, and Response: Managing Emerging Diseases at National and International Levels,' Revue Scientifiqueet Technique (International Office of Epizootics) 23(2), pp.709-15.

Lai, A. Y. (2012a), 'Organizational Collaborative Capacity in Fighting Pandemic Crises: A Literature Review from the Public Management Perspective', AsiaPacific Journal of Public Health 24(1), pp.1-14.

Lai, A. Y. (2012b), 'Toward a Collaborative Cross-Border Disaster Management: A Comparative Analysis of Voluntary Organizations in Taiwan and Singapore,' Journal of Comparative Policy Analysis 14(3), pp.1-18.

Lai, A. Y. (2011), 'Organizational Collaborative Capacities in Post Disaster Society,' Asian Journal of Social Science 39(4), pp.442-64.

Lai, A. Y. (2010), 'Shaping the Crisis Perception of Decision Makers and Its Application of Singapore's Voluntary Contribution to Post-Tsunami Reconstruction Efforts,' Journal of Administration and Governance 4(2), pp.1-12.

Lai, A. Y. (2009), 'Shaping the Crisis Perception of Decision Makers and Its Application of Singapore's Voluntary Contribution to Post-Tsunami Reconstruction Efforts', Journal of Administration and Governance 4(2), pp.1-12.

Lai, A. Y., A. J. He, T. B. Tan, and K.H. Phua (2009), 'A Proposed ASEAN Disaster Response, Training and Logistic Centre: Enhancing Regional Governance in Disaster Management,' Transition Studies Reviews 16(2), pp.299-315.

Lai, A. Y., and T. B. Tan (2012), 'Combating SARS and H1N1: Insights and Lessons from Singapore's Public Health Control Measures,' ASEAS - Austrian Journal of South-East Asian Studies 5(1), pp.74-101.

LaPorte, T. R. (2007), 'Critical Infrastructure in the Face of a Predatory Future: Preparing for Untoward Surprise,' Journal of Contingencies and Crisis Management 15(1), pp.60-64. 
Leung, G. M. and A. Nicoll (2010), 'Reflections on Pandemic (H1N1) 2009 and the International Response', PLoS Medicine 7(10), e1000346.

Meier, K. J. and L. J. Jr. O’Toole (2001), 'Managerial Strategies and Behavior in Networks: A Model with Evidence from U.S. Public Education', Journal of Public Administration Research and Theory 11(July), pp.271-95.

Menon, K. U. and K. T. Goh (2005), 'Transparency and Trust: Risk Communications and the Singapore Experience in Managing SARS,' Journal of Communication Management 9(4), pp.375-83.

Ministry of Health, Singapore (2003a), 'Daily Distribution of SARS Cases Statistics', Singapore Government. http://www.moh.gov.sg/content/moh_web/home/ diseases_and_conditions/s/sars.html (accessed June 29, 2012)

Ministry of Health, Singapore (2003b), 'Chronology of SARS Events in Singapore', Singapore Government. http://www.moh.gov.sg/corp/sars/news/chronology. html (accessed June 29, 2012)

Ministry of Labour, Singapore (1979), 'The Explosion and Fire on Board S.T. Spyros, $12^{\text {th }}$ October 1978: The Inquiry Report', Committee of Inquiry into the Explosion and Fire on Board S.T. Spyros (Call no.: RSING 623.83 SIN). Inflopedia [online]. http://infopedia.nl.sg/articles/SIP_806_2004-12-30.html (accessed June 29, 2012)

Ministry of Manpower, Singapore (2003), 'Manpower Research and Statistics', Singapore Government. http://www.mom.gov.sg/publish/momportal/en/ communities/others/mrsd/statistics/Unemployment.html (accessed June 29, 2012)

Monetary Authority Singapore (2003/2004), ‘Annual Report', Singapore Government. http://www.mas.gov.sg/about_us/annual_reports/annual2003 2004/pdf/mas annualReport (accessed June 29, 2012)

Narain J., and R. Bhatia (2010), 'The Challenge of Communicable Diseases in the WHO South-east Asia Region,' Bull World Health Organ, 88, 162. http://www.who.int/bulletin/volumes/88/3/09-065169/en/index.html (accessed June 29, 2012)

Oshitani, H., T. Kamigaki, and A. Suzuki (2008), 'Major Issues and Challenges of Influenza Pandemic Preparedness in Developing Countries', Emerging Infectious Diseases 14(6), pp.875-80.

Pereira, D. (2008), 'Crisis Management in the Homefront', Presentation at Network Government and Homeland Security Workshop, Singapore, 7 January 2008.

Putthasri, W., J. Lertiendumrong, P. Chompook, V. Tangcharoensathien, V., and R. Coker (2009), 'Capacity of Thailand to Contain an Emerging Influenza Pandemic’, Emerging Infectious Diseases 15(3), pp.423-32.

Reddy, M.C., S. A. Paul, J. Abraham, M. McNeese, C. DeFitch, and J. Yen (2009), 'Challenges to Effective Crisis Management: Using Information and Communication Technologies to Coordinate Emergency Medical Services 
and Emergency Department Teams', International Journal of Medical Informatics 78, pp.259-69.

Reynolds, B. and M. W. Seeger (2005), 'Crisis and Emergency Risk Communication as an Integrative Model,' Journal of Health Communication 10, pp.43-55.

Shalala, D. E. (1998), 'Collaboration in the Fight against Infectious Diseases', Emerging Infectious Disease 4(3), pp.355-58.

Singapore Department of Statistics (2003), 'Economic Survey of Singapore 2003', Singapore Government. http://www.singstat.gov.sg/(accessed April 15, 2012)

Singapore Institute of International Affairs (2006), 'Singapore's Efforts in Transboundary Haze Prevention, 2006', Singapore: SIIA. http:// http://www.siiaonline.org/?q=events/singapores-efforts-transboundary-hazeprevention (accessed June 29, 2012).

Singapore Real Estate (2011), Singapore Real Estate, and Property Price. Available at http://www.singaporerealestate.info/blog/property-tools/spsf-chart-d09-10/, http://www.h88.com.sg/property_stats/property_price_index.php_ (accessed June 29, 2012).

Singapore Tourism Board.(2002), Annual Report on Tourism Statistics. Singapore.

Singapore Tourism Board.(2003), Annual Report on Tourism Statistics. Singapore.

Singapore Tourism Board.(2004), Annual Report on Tourism Statistics. Singapore.

Tan, C. C. (2006), 'SARS in Singapore - Key Lessons from an Epidemic,' Ann Acad Med Singapore 35, pp.345-349.

Tan, L. Y. (1978), 1978 Singapore Floods. Singapore Inflopedia [online]. http://infopedia.nl.sg/articles/SIP 780_2004-12-30.html (accessed June 29, 2012).

Tay, C. B., and W. K. Mui (2004), An Architecture for Network Centric Operations in Unconventional Crisis: Lessons Learnt from Singapore's SARS Experience. California: Thesis of Naval Postgraduate School.

Teo, P., B. S. A. Yeoh and S. N. Ong (2005), 'SARS in Singapore: Surveillance Strategies in a Globalizing City’, Health Policy 72(3), pp.279-91.

Voo, T. C., and B. Capps (2010), 'Influenza Pandemic and the Duties of Healthcare Professionals', Singapore Medical Journal 51(4), pp.275-81.

Webby, R. J., and R. G. Webster (2003), 'Are We Ready for Pandemic Influenza?' Science 302(5650), pp1519-22

World Health Organization (2005), WHO Guidelines on the Use of Vaccines and Antivirals during Influenza Pandemics. Geneva: Word Health Organization, 2004. $\quad$ http://www.who.int/csr/resources/publications/influenza/11_29_01 A.pdf (accessed June 29, 2012).

World Health Organization (2003a), Update 70-Singapore Removed from List of Areas with Local SARS Transmission. WHO. http://www.who.int/csr/don /2003_05_30a/en/index.html (accessed June 29, 2012). 
World Health Organization (2003b), Summary of Probable SARS Cases with Onset of illness from; 1 November 2002 to 31 July 2003 (based on data as of the 31 December; 2003). WHO. http://www.who.int/csr/sars/country/table2004_04_21/en/index.html (accessed June 29, 2012).

\section{ENDNOTES}

${ }^{1}$ Lai Yu-Hung Allen is the Director of Institute of Health Economics and Management, ESSEC Business School - Asia Pacific. He holds a doctoral degree in public policy from National University of Singapore. Dr. Lai has published widely in health management, policy analysis, crisis management, and pandemic management. His current research interests include collaborative capacity, network governance, and organisational learning in public health crises. Contact: allen.yuhung@gmail.com (corresponding author).

${ }^{2}$ Seck L. Tan is a PhD at the Lee Kuan Yew School of Public Policy, National University of Singapore. His current research interests include macroeconomics, environmental macroeconomics, and formulating sustainable development policies. Contact: seck.tan@nus.edu.sg

${ }^{3}$ One of the authors, Allen Lai, has been working on the rescue mission in fighting SARS in 2003.

${ }^{4}$ EM-DAT is one of the most exhaustive sources of data available in the global emergency events database on disasters (natural and technological hazards).

${ }^{5}$ According to 2006 data, SCDF has a workforce of about 5,100 staff comprising of 1,700 regular uniformed staff, 200 civilian staff and 3,200 full-time National Servicemen. The budget size for SCDF on a national level is about SGD\$300 million per annum.

${ }^{6}$ Prior to SARS in 2003, the Executive Group in the Homefront Crisis Management System was the key executive body charged with managing peacetime crises in Singapore.

${ }^{7}$ Other than Ministries of Home Affairs and Health, the Inter-Ministerial Committee comprised other eight ministries: Foreign Affairs, Defence, Education, National Development, Manpower, Environment, Transport and Information, Communications and the Arts.

${ }^{8}$ Singapore government dispensed a total of SGD $300 \mathrm{~m}$ to battle SARS directly and SGD230m to help business, on 1 July 2003.

${ }^{9}$ These measures were agreed by the tripartite partners who issued a tripartite statement on 15 April 2003. The tripartite approach reflects the willingness and ability of the three social partners to work together to face the crisis (Source: NWC Recommendations for 2003/2004).

${ }^{10}$ Personal protective equipment includes N95 masks, disposable gloves, gowns, and goggles or visors. 


\section{ERIA Discussion Paper Series}

\begin{tabular}{|c|c|c|c|}
\hline No. & Author(s) & Title & Year \\
\hline $2013-14$ & $\begin{array}{l}\text { Allen Yu-Hung LAI and } \\
\text { Seck L. TAN }\end{array}$ & $\begin{array}{l}\text { Impact of Disasters and Disaster Risk Management in } \\
\text { Singapore: A Case Study of Singapore's Experience } \\
\text { in Fighting the SARS Epidemic }\end{array}$ & $\begin{array}{l}\text { Aug } \\
2013\end{array}$ \\
\hline $2013-13$ & Brent LAYTON & $\begin{array}{l}\text { Impact of Natural Disasters on Production Networks } \\
\text { and Urbanization in New Zealand }\end{array}$ & $\begin{array}{l}\text { Aug } \\
2013\end{array}$ \\
\hline $2013-12$ & Mitsuyo ANDO & $\begin{array}{l}\text { Impact of Recent Crises and Disasters on Regional } \\
\text { Production/Distribution Networks and Trade in Japan }\end{array}$ & $\begin{array}{l}\text { Aug } \\
2013\end{array}$ \\
\hline 2013-11 & Le Dang TRUNG & $\begin{array}{l}\text { Economic and Welfare Impacts of Disasters in East } \\
\text { Asia and Policy Responses: The Case of Vietnam }\end{array}$ & $\begin{array}{l}\text { Aug } \\
2013\end{array}$ \\
\hline $2013-10$ & $\begin{array}{l}\text { Sann VATHANA, Sothea } \\
\text { OUM, Ponhrith KAN, } \\
\text { Colas CHERVIER }\end{array}$ & $\begin{array}{l}\text { Impact of Disasters and Role of Social Protection in } \\
\text { Natural Disaster Risk Management in Cambodia }\end{array}$ & $\begin{array}{l}\text { Aug } \\
2013\end{array}$ \\
\hline 2013-09 & $\begin{array}{l}\text { Sommarat CHANTARAT, } \\
\text { Krirk PANNANGPETCH, } \\
\text { Nattapong } \\
\text { PUTTANAPONG, Preesan } \\
\text { RAKWATIN, and Thanasin } \\
\text { TANOMPONGPHANDH }\end{array}$ & $\begin{array}{l}\text { Index-Based Risk Financing and Development of } \\
\text { Natural Disaster Insurance Programs in Developing } \\
\text { Asian Countries }\end{array}$ & $\begin{array}{l}\text { Aug } \\
2013\end{array}$ \\
\hline 2013-08 & $\begin{array}{l}\text { Ikumo ISONO and Satoru } \\
\text { KUMAGAI }\end{array}$ & $\begin{array}{l}\text { Long-run Economic Impacts of Thai Flooding: } \\
\text { Geographical Simulation Analysis }\end{array}$ & $\begin{array}{l}\text { July } \\
2013\end{array}$ \\
\hline 2013-07 & $\begin{array}{l}\text { Yoshifumi FUKUNAGA } \\
\text { and Hikaru ISHIDO }\end{array}$ & $\begin{array}{l}\text { Assessing the Progress of Services Liberalization in } \\
\text { the ASEAN-China Free Trade Area (ACFTA) }\end{array}$ & $\begin{array}{l}\text { May } \\
2013\end{array}$ \\
\hline 2013-06 & $\begin{array}{l}\text { Ken ITAKURA, Yoshifumi } \\
\text { FUKUNAGA, and Ikumo } \\
\text { ISONO }\end{array}$ & $\begin{array}{l}\text { A CGE Study of Economic Impact of Accession of } \\
\text { Hong Kong to ASEAN-China Free Trade Agreement }\end{array}$ & $\begin{array}{l}\text { May } \\
2013\end{array}$ \\
\hline 2013-05 & $\begin{array}{l}\text { Misa OKABE and Shujiro } \\
\text { URATA }\end{array}$ & The Impact of AFTA on Intra-AFTA Trade & $\begin{array}{l}\text { May } \\
2013\end{array}$ \\
\hline 2013-04 & Kohei SHIINO & $\begin{array}{l}\text { How Far Will Hong Kong's Accession to ACFTA will } \\
\text { Impact on Trade in Goods? }\end{array}$ & $\begin{array}{l}\text { May } \\
2013\end{array}$ \\
\hline 2013-03 & $\begin{array}{l}\text { Cassey LEE and Yoshifumi } \\
\text { FUKUNAGA }\end{array}$ & $\begin{array}{l}\text { ASEAN Regional Cooperation on Competition } \\
\text { Policy }\end{array}$ & $\begin{array}{l}\text { Apr } \\
2013\end{array}$ \\
\hline 2013-02 & Yoshifumi FUKUNAGA & Taking ASEAN+1 FTAs towards the RCEP: & Jan \\
\hline
\end{tabular}




\begin{tabular}{|c|c|c|c|}
\hline No. & Author(s) & Title & Year \\
\hline & and Ikumo ISONO & A Mapping Study & 2013 \\
\hline 2013-01 & Ken ITAKURA & $\begin{array}{l}\text { Impact of Liberalization and Improved Connectivity } \\
\text { and Facilitation in ASEAN for the ASEAN Economic } \\
\text { Community }\end{array}$ & $\begin{array}{l}\text { Jan } \\
2013\end{array}$ \\
\hline $2012-17$ & $\begin{array}{l}\text { Sun XUEGONG, Guo } \\
\text { LIYAN, Zeng ZHENG }\end{array}$ & $\begin{array}{l}\text { Market Entry Barriers for FDI and Private Investors: } \\
\text { Lessons from China's Electricity Market }\end{array}$ & $\begin{array}{l}\text { Aug } \\
2012\end{array}$ \\
\hline $2012-16$ & Yanrui WU & $\begin{array}{l}\text { Electricity Market Integration: Global Trends and } \\
\text { Implications for the EAS Region }\end{array}$ & $\begin{array}{l}\text { Aug } \\
2012\end{array}$ \\
\hline $2012-15$ & $\begin{array}{l}\text { Youngho CHANG, Yanfei } \\
\text { LI }\end{array}$ & $\begin{array}{l}\text { Power Generation and Cross-border Grid Planning for } \\
\text { the Integrated ASEAN Electricity Market: A Dynamic } \\
\text { Linear Programming Model }\end{array}$ & $\begin{array}{l}\text { Aug } \\
2012\end{array}$ \\
\hline $2012-14$ & Yanrui WU, Xunpeng SHI & $\begin{array}{l}\text { Economic Development, Energy Market Integration and } \\
\text { Energy Demand: Implications for East Asia }\end{array}$ & $\begin{array}{l}\text { Aug } \\
2012\end{array}$ \\
\hline $2012-13$ & $\begin{array}{l}\text { Joshua AIZENMAN, } \\
\text { Minsoo LEE, and } \\
\text { Donghyun PARK }\end{array}$ & $\begin{array}{l}\text { The Relationship between Structural Change and } \\
\text { Inequality: A Conceptual Overview with Special } \\
\text { Reference to Developing Asia }\end{array}$ & $\begin{array}{l}\text { July } \\
2012\end{array}$ \\
\hline $2012-12$ & $\begin{array}{l}\text { Hyun-Hoon LEE, Minsoo } \\
\text { LEE, and Donghyun PARK }\end{array}$ & $\begin{array}{l}\text { Growth Policy and Inequality in Developing Asia: } \\
\text { Lessons from Korea }\end{array}$ & $\begin{array}{l}\text { July } \\
2012\end{array}$ \\
\hline $2012-11$ & Cassey LEE & $\begin{array}{l}\text { Knowledge Flows, Organization and Innovation: } \\
\text { Firm-Level Evidence from Malaysia }\end{array}$ & $\begin{array}{l}\text { June } \\
2012\end{array}$ \\
\hline $2012-10$ & $\begin{array}{l}\text { Jacques MAIRESSE, Pierre } \\
\text { MOHNEN, Yayun ZHAO, } \\
\text { and Feng ZHEN }\end{array}$ & $\begin{array}{l}\text { Globalization, Innovation and Productivity in } \\
\text { Manufacturing Firms: A Study of Four Sectors of China }\end{array}$ & $\begin{array}{l}\text { June } \\
2012\end{array}$ \\
\hline 2012-09 & Ari KUNCORO & $\begin{array}{l}\text { Globalization and Innovation in Indonesia: Evidence } \\
\text { from Micro-Data on Medium and Large Manufacturing } \\
\text { Establishments }\end{array}$ & $\begin{array}{l}\text { June } \\
2012\end{array}$ \\
\hline $2012-08$ & Alfons PALANGKARAYA & $\begin{array}{l}\text { The Link between Innovation and Export: Evidence } \\
\text { from Australia's Small and Medium Enterprises }\end{array}$ & $\begin{array}{l}\text { June } \\
2012\end{array}$ \\
\hline $2012-07$ & $\begin{array}{l}\text { Chin Hee HAHN and } \\
\text { Chang-Gyun PARK }\end{array}$ & $\begin{array}{l}\text { Direction of Causality in Innovation-Exporting Linkage: } \\
\text { Evidence on Korean Manufacturing }\end{array}$ & $\begin{array}{l}\text { June } \\
2012\end{array}$ \\
\hline $2012-06$ & Keiko ITO & $\begin{array}{l}\text { Source of Learning-by-Exporting Effects: Does } \\
\text { Exporting Promote Innovation? }\end{array}$ & $\begin{array}{l}\text { June } \\
2012\end{array}$ \\
\hline $2012-05$ & Rafaelita M. ALDABA & $\begin{array}{l}\text { Trade Reforms, Competition, and Innovation in the } \\
\text { Philippines }\end{array}$ & $\begin{array}{l}\text { June } \\
2012\end{array}$ \\
\hline
\end{tabular}




\begin{tabular}{|c|c|c|c|}
\hline No. & Author(s) & Title & Year \\
\hline $2012-04$ & $\begin{array}{l}\text { Toshiyuki MATSUURA } \\
\text { and Kazunobu } \\
\text { HAYAKAWA }\end{array}$ & $\begin{array}{l}\text { The Role of Trade Costs in FDI Strategy of } \\
\text { Heterogeneous Firms: Evidence from Japanese } \\
\text { Firm-level Data }\end{array}$ & $\begin{array}{l}\text { June } \\
2012\end{array}$ \\
\hline $2012-03$ & $\begin{array}{l}\text { Kazunobu HAYAKAWA, } \\
\text { Fukunari KIMURA, and } \\
\text { Hyun-Hoon LEE }\end{array}$ & $\begin{array}{l}\text { How Does Country Risk Matter for Foreign Direct } \\
\text { Investment? }\end{array}$ & $\begin{array}{l}\text { Feb } \\
2012\end{array}$ \\
\hline $2012-02$ & $\begin{array}{l}\text { Ikumo ISONO, Satoru } \\
\text { KUMAGAI, Fukunari } \\
\text { KIMURA }\end{array}$ & $\begin{array}{l}\text { Agglomeration and Dispersion in China and ASEAN: } \\
\text { A Geographical Simulation Analysis }\end{array}$ & $\begin{array}{l}\text { Jan } \\
2012\end{array}$ \\
\hline $2012-01$ & $\begin{array}{l}\text { Mitsuyo ANDO and } \\
\text { Fukunari KIMURA }\end{array}$ & $\begin{array}{l}\text { How Did the Japanese Exports Respond to Two Crises } \\
\text { in the International Production Network?: The Global } \\
\text { Financial Crisis and the East Japan Earthquake }\end{array}$ & $\begin{array}{l}\text { Jan } \\
2012\end{array}$ \\
\hline $2011-10$ & $\begin{array}{l}\text { Tomohiro MACHIKITA } \\
\text { and Yasushi UEKI }\end{array}$ & $\begin{array}{l}\text { Interactive Learning-driven Innovation in } \\
\text { Upstream-Downstream Relations: Evidence from } \\
\text { Mutual Exchanges of Engineers in Developing } \\
\text { Economies }\end{array}$ & $\begin{array}{l}\text { Dec } \\
2011\end{array}$ \\
\hline 2011-09 & $\begin{array}{l}\text { Joseph D. ALBA, Wai-Mun } \\
\text { CHIA, and Donghyun } \\
\text { PARK }\end{array}$ & $\begin{array}{l}\text { Foreign Output Shocks and Monetary Policy Regimes } \\
\text { in Small Open Economies: A DSGE Evaluation of East } \\
\text { Asia }\end{array}$ & $\begin{array}{l}\text { Dec } \\
2011\end{array}$ \\
\hline 2011-08 & $\begin{array}{l}\text { Tomohiro MACHIKITA } \\
\text { and Yasushi UEKI }\end{array}$ & $\begin{array}{l}\text { Impacts of Incoming Knowledge on Product Innovation: } \\
\text { Econometric Case Studies of Technology Transfer of } \\
\text { Auto-related Industries in Developing Economies }\end{array}$ & $\begin{array}{l}\text { Nov } \\
2011\end{array}$ \\
\hline 2011-07 & Yanrui WU & $\begin{array}{l}\text { Gas Market Integration: Global Trends and Implications } \\
\text { for the EAS Region }\end{array}$ & $\begin{array}{l}\text { Nov } \\
2011\end{array}$ \\
\hline $2011-06$ & Philip Andrews-SPEED & $\begin{array}{l}\text { Energy Market Integration in East Asia: A Regional } \\
\text { Public Goods Approach }\end{array}$ & $\begin{array}{l}\text { Nov } \\
2011\end{array}$ \\
\hline $2011-05$ & $\begin{array}{l}\text { Yu SHENG, } \\
\text { Xunpeng SHI }\end{array}$ & $\begin{array}{l}\text { Energy Market Integration and Economic } \\
\text { Convergence: Implications for East Asia }\end{array}$ & $\begin{array}{l}\text { Oct } \\
2011\end{array}$ \\
\hline 2011-04 & $\begin{array}{l}\text { Sang-Hyop LEE, Andrew } \\
\text { MASON, and Donghyun } \\
\text { PARK }\end{array}$ & $\begin{array}{l}\text { Why Does Population Aging Matter So Much for } \\
\text { Asia? Population Aging, Economic Security and } \\
\text { Economic Growth in Asia }\end{array}$ & $\begin{array}{l}\text { Aug } \\
2011\end{array}$ \\
\hline $2011-03$ & $\begin{array}{l}\text { Xunpeng SHI, } \\
\text { Shinichi GOTO }\end{array}$ & $\begin{array}{l}\text { Harmonizing Biodiesel Fuel Standards in East Asia: } \\
\text { Current Status, Challenges and the Way Forward }\end{array}$ & $\begin{array}{l}\text { May } \\
2011\end{array}$ \\
\hline
\end{tabular}




\begin{tabular}{|c|c|c|c|}
\hline No. & Author(s) & Title & Year \\
\hline 2011-02 & Hikari ISHIDO & $\begin{array}{l}\text { Liberalization of Trade in Services under ASEAN }+n \text { : } \\
\text { A Mapping Exercise }\end{array}$ & $\begin{array}{l}\text { May } \\
2011\end{array}$ \\
\hline 2011-01 & $\begin{array}{l}\text { Kuo-I CHANG, Kazunobu } \\
\text { HAYAKAWA } \\
\text { Toshiyuki MATSUURA }\end{array}$ & $\begin{array}{l}\text { Location Choice of Multinational Enterprises in } \\
\text { China: Comparison between Japan and Taiwan }\end{array}$ & $\begin{array}{l}\text { Mar } \\
2011\end{array}$ \\
\hline 2010-11 & $\begin{array}{l}\text { Charles HARVIE, } \\
\text { Dionisius NARJOKO, } \\
\text { Sothea OUM }\end{array}$ & $\begin{array}{l}\text { Firm Characteristic Determinants of SME } \\
\text { Participation in Production Networks }\end{array}$ & $\begin{array}{l}\text { Oct } \\
2010\end{array}$ \\
\hline 2010-10 & Mitsuyo ANDO & $\begin{array}{l}\text { Machinery Trade in East Asia, and the Global } \\
\text { Financial Crisis }\end{array}$ & $\begin{array}{l}\text { Oct } \\
2010\end{array}$ \\
\hline 2010-09 & $\begin{array}{l}\text { Fukunari KIMURA } \\
\text { Ayako OBASHI }\end{array}$ & $\begin{array}{l}\text { International Production Networks in Machinery } \\
\text { Industries: Structure and Its Evolution }\end{array}$ & $\begin{array}{l}\text { Sep } \\
2010\end{array}$ \\
\hline 2010-08 & $\begin{array}{l}\text { Tomohiro MACHIKITA, } \\
\text { Shoichi MIYAHARA, } \\
\text { Masatsugu TSUJI, and } \\
\text { Yasushi UEKI }\end{array}$ & $\begin{array}{l}\text { Detecting Effective Knowledge Sources in Product } \\
\text { Innovation: Evidence from Local Firms and } \\
\text { MNCs/JVs in Southeast Asia }\end{array}$ & $\begin{array}{l}\text { Aug } \\
2010\end{array}$ \\
\hline 2010-07 & $\begin{array}{l}\text { Tomohiro MACHIKITA, } \\
\text { Masatsugu TSUJI, and } \\
\text { Yasushi UEKI }\end{array}$ & $\begin{array}{l}\text { How ICTs Raise Manufacturing Performance: } \\
\text { Firm-level Evidence in Southeast Asia }\end{array}$ & $\begin{array}{l}\text { Aug } \\
2010\end{array}$ \\
\hline 2010-06 & Xunpeng SHI & $\begin{array}{l}\text { Carbon Footprint Labeling Activities in the East Asia } \\
\text { Summit Region: Spillover Effects to Less Developed } \\
\text { Countries }\end{array}$ & $\begin{array}{l}\text { July } \\
2010\end{array}$ \\
\hline 2010-05 & $\begin{array}{l}\text { Kazunobu HAYAKAWA, } \\
\text { Fukunari KIMURA, and } \\
\text { Tomohiro MACHIKITA }\end{array}$ & $\begin{array}{l}\text { Firm-level Analysis of Globalization: A Survey of the } \\
\text { Eight Literatures }\end{array}$ & $\begin{array}{l}\text { Mar } \\
2010\end{array}$ \\
\hline 2010-04 & $\begin{array}{l}\text { Tomohiro MACHIKITA } \\
\text { and Yasushi UEKI }\end{array}$ & $\begin{array}{l}\text { The Impacts of Face-to-face and Frequent } \\
\text { Interactions on Innovation: } \\
\text { Upstream-Downstream Relations }\end{array}$ & $\begin{array}{l}\text { Feb } \\
2010\end{array}$ \\
\hline 2010-03 & $\begin{array}{l}\text { Tomohiro MACHIKITA } \\
\text { and Yasushi UEKI }\end{array}$ & $\begin{array}{l}\text { Innovation in Linked and Non-linked Firms: } \\
\text { Effects of Variety of Linkages in East Asia }\end{array}$ & $\begin{array}{l}\text { Feb } \\
2010\end{array}$ \\
\hline 2010-02 & $\begin{array}{l}\text { Tomohiro MACHIKITA } \\
\text { and Yasushi UEKI }\end{array}$ & $\begin{array}{l}\text { Search-theoretic Approach to Securing New } \\
\text { Suppliers: Impacts of Geographic Proximity for } \\
\text { Importer and Non-importer }\end{array}$ & $\begin{array}{l}\text { Feb } \\
2010\end{array}$ \\
\hline
\end{tabular}




\begin{tabular}{|c|c|c|c|}
\hline No. & Author(s) & Title & Year \\
\hline 2010-01 & $\begin{array}{l}\text { Tomohiro MACHIKITA } \\
\text { and Yasushi UEKI }\end{array}$ & $\begin{array}{l}\text { Spatial Architecture of the Production Networks in } \\
\text { Southeast Asia: } \\
\text { Empirical Evidence from Firm-level Data }\end{array}$ & $\begin{array}{l}\text { Feb } \\
2010\end{array}$ \\
\hline $2009-23$ & Dionisius NARJOKO & $\begin{array}{l}\text { Foreign Presence Spillovers and Firms' Export } \\
\text { Response: } \\
\text { Evidence from the Indonesian Manufacturing }\end{array}$ & $\begin{array}{l}\text { Nov } \\
2009\end{array}$ \\
\hline $2009-22$ & $\begin{array}{l}\text { Kazunobu HAYAKAWA, } \\
\text { Daisuke HIRATSUKA, } \\
\text { Kohei SHIINO, and Seiya } \\
\text { SUKEGAWA }\end{array}$ & Who Uses Free Trade Agreements? & $\begin{array}{l}\text { Nov } \\
2009\end{array}$ \\
\hline $2009-21$ & Ayako OBASHI & $\begin{array}{l}\text { Resiliency of Production Networks in Asia: } \\
\text { Evidence from the Asian Crisis }\end{array}$ & $\begin{array}{l}\text { Oct } \\
2009\end{array}$ \\
\hline $2009-20$ & $\begin{array}{l}\text { Mitsuyo ANDO and } \\
\text { Fukunari KIMURA }\end{array}$ & Fragmentation in East Asia: Further Evidence & $\begin{array}{l}\text { Oct } \\
2009\end{array}$ \\
\hline 2009-19 & Xunpeng SHI & $\begin{array}{l}\text { The Prospects for Coal: Global Experience and } \\
\text { Implications for Energy Policy }\end{array}$ & $\begin{array}{l}\text { Sept } \\
2009\end{array}$ \\
\hline $2009-18$ & Sothea OUM & $\begin{array}{l}\text { Income Distribution and Poverty in a CGE } \\
\text { Framework: A Proposed Methodology }\end{array}$ & $\begin{array}{l}\text { Jun } \\
2009\end{array}$ \\
\hline $2009-17$ & $\begin{array}{l}\text { Erlinda M. MEDALLA } \\
\text { and Jenny BALBOA }\end{array}$ & $\begin{array}{l}\text { ASEAN Rules of Origin: Lessons and } \\
\text { Recommendations for the Best Practice }\end{array}$ & $\begin{array}{l}\text { Jun } \\
2009\end{array}$ \\
\hline $2009-16$ & Masami ISHIDA & Special Economic Zones and Economic Corridors & $\begin{array}{l}\text { Jun } \\
2009\end{array}$ \\
\hline $2009-15$ & Toshihiro KUDO & $\begin{array}{l}\text { Border Area Development in the GMS: Turning the } \\
\text { Periphery into the Center of Growth }\end{array}$ & $\begin{array}{l}\text { May } \\
2009\end{array}$ \\
\hline 2009-14 & $\begin{array}{l}\text { Claire HOLLWEG and } \\
\text { Marn-Heong WONG }\end{array}$ & $\begin{array}{l}\text { Measuring Regulatory Restrictions in Logistics } \\
\text { Services }\end{array}$ & $\begin{array}{l}\text { Apr } \\
2009\end{array}$ \\
\hline $2009-13$ & Loreli C. De DIOS & Business View on Trade Facilitation & $\begin{array}{l}\text { Apr } \\
2009\end{array}$ \\
\hline $2009-12$ & $\begin{array}{l}\text { Patricia SOURDIN and } \\
\text { Richard POMFRET }\end{array}$ & Monitoring Trade Costs in Southeast Asia & $\begin{array}{l}\text { Apr } \\
2009\end{array}$ \\
\hline $2009-11$ & $\begin{array}{l}\text { Philippa DEE and } \\
\text { Huong DINH }\end{array}$ & $\begin{array}{l}\text { Barriers to Trade in Health and Financial Services in } \\
\text { ASEAN }\end{array}$ & $\begin{array}{l}\text { Apr } \\
2009\end{array}$ \\
\hline $2009-10$ & Sayuri SHIRAI & $\begin{array}{l}\text { The Impact of the US Subprime Mortgage Crisis on } \\
\text { the World and East Asia: Through Analyses of } \\
\text { Cross-border Capital Movements }\end{array}$ & $\begin{array}{l}\text { Apr } \\
2009\end{array}$ \\
\hline
\end{tabular}




\begin{tabular}{|c|c|c|c|}
\hline No. & Author(s) & Title & Year \\
\hline 2009-09 & $\begin{array}{l}\text { Mitsuyo ANDO and } \\
\text { Akie IRIYAMA }\end{array}$ & $\begin{array}{l}\text { International Production Networks and Export/Import } \\
\text { Responsiveness to Exchange Rates: The Case of } \\
\text { Japanese Manufacturing Firms }\end{array}$ & $\begin{array}{l}\text { Mar } \\
2009\end{array}$ \\
\hline 60,08 & Archanun & Vertical and Horizontal FDI Technology & Mar \\
\hline $9-08$ & KOHPAIBOON & Spillovers:Evidence from Thai Manufacturing & 2009 \\
\hline $2009-07$ & $\begin{array}{l}\text { Kazunobu HAYAKAWA, } \\
\text { Fukunari KIMURA, and } \\
\text { Toshiyuki MATSUURA }\end{array}$ & $\begin{array}{l}\text { Gains from Fragmentation at the Firm Level: } \\
\text { Evidence from Japanese Multinationals in East Asia }\end{array}$ & $\begin{array}{l}\text { Mar } \\
2009\end{array}$ \\
\hline 2009-06 & Dionisius A. NARJOKO & $\begin{array}{l}\text { Plant Entry in a More } \\
\text { LiberalisedIndustrialisationProcess: An Experience } \\
\text { of Indonesian Manufacturing during the 1990s }\end{array}$ & $\begin{array}{l}\text { Mar } \\
2009\end{array}$ \\
\hline $2009-05$ & $\begin{array}{l}\text { Kazunobu HAYAKAWA, } \\
\text { Fukunari KIMURA, and } \\
\text { Tomohiro MACHIKITA }\end{array}$ & Firm-level Analysis of Globalization: A Survey & $\begin{array}{l}\text { Mar } \\
2009\end{array}$ \\
\hline 2009-04 & $\begin{array}{l}\text { Chin Hee HAHN and } \\
\text { Chang-Gyun PARK }\end{array}$ & $\begin{array}{l}\text { Learning-by-exporting in Korean Manufacturing: } \\
\text { A Plant-level Analysis }\end{array}$ & $\begin{array}{l}\text { Mar } \\
2009\end{array}$ \\
\hline 2009-03 & Ayako OBASHI & $\begin{array}{l}\text { Stability of Production Networks in East Asia: } \\
\text { Duration and Survival of Trade }\end{array}$ & $\begin{array}{l}\text { Mar } \\
2009\end{array}$ \\
\hline 2009-02 & Fukunari KIMURA & $\begin{array}{l}\text { The Spatial Structure of Production/Distribution } \\
\text { Networks and Its Implication for Technology } \\
\text { Transfers and Spillovers }\end{array}$ & $\begin{array}{l}\text { Mar } \\
2009\end{array}$ \\
\hline 2009-01 & $\begin{array}{l}\text { Fukunari KIMURA and } \\
\text { Ayako OBASHI }\end{array}$ & $\begin{array}{l}\text { International Production Networks: Comparison } \\
\text { between China and ASEAN }\end{array}$ & $\begin{array}{l}\text { Jan } \\
2009\end{array}$ \\
\hline $2008-03$ & $\begin{array}{l}\text { Kazunobu HAYAKAWA } \\
\text { and Fukunari KIMURA }\end{array}$ & $\begin{array}{l}\text { The Effect of Exchange Rate Volatility on } \\
\text { International Trade in East Asia }\end{array}$ & $\begin{array}{l}\text { Dec } \\
2008\end{array}$ \\
\hline $2008-02$ & $\begin{array}{l}\text { Satoru KUMAGAI, } \\
\text { Toshitaka GOKAN, } \\
\text { Ikumo ISONO, and } \\
\text { Souknilanh KEOLA }\end{array}$ & $\begin{array}{l}\text { Predicting Long-Term Effects of Infrastructure } \\
\text { Development Projects in Continental South East } \\
\text { Asia: IDE Geographical Simulation Model }\end{array}$ & $\begin{array}{l}\text { Dec } \\
2008\end{array}$ \\
\hline $2008-01$ & $\begin{array}{l}\text { Kazunobu HAYAKAWA, } \\
\text { Fukunari KIMURA, and } \\
\text { Tomohiro MACHIKITA }\end{array}$ & Firm-level Analysis of Globalization: A Survey & $\begin{array}{l}\text { Dec } \\
2008\end{array}$ \\
\hline
\end{tabular}

